\title{
GREEN SYNTHESIS: NANOPARTICLES AND NANOFIBRES BASED ON TREE GUMS FOR ENVIRONMENTAL APPLICATIONS
}

\author{
ZIELONA SYNTEZA: NANOCZĄSTKI I NANOWŁÓKNA WYTWORZONE \\ Z NATURALNYCH GUM I ICH ŚRODOWISKOWE ZASTOSOWANIE
}

\begin{abstract}
The recent advances and potential applications of nanoparticles and nanofibres for energy, water, food, biotechnology, the environment, and medicine have immensely conversed. The present review describes a 'green' method for the synthesis and stabilization of nanoparticles and 'green electrospinning' both using tree gums (arabic, tragacanth, karaya and kondagogu). Furthermore, this review focuses on the impending applications of both gum stabilized nanoparticles and functionalized membranes in remediation of toxic metals, radioactive effluents, and the adsorptive removal of nanoparticulates from aqueous environments as well as from industrial effluents. Besides, the antibacterial properties of gum derivatives, gum stabilized nanoparticles, and functionalized electrospun nanofibrous membranes will also be highlighted. The functionalities of nanofibrous membranes that can be enhanced by various plasma treatments (oxygen and methane, respectively) will also be emphasized.
\end{abstract}

Keywords: tree gums, nanoparticles, green electrospinning, environmental remediation, antibacterial membranes, oxygen and methane plasma treatments

\section{Introduction}

In the past few decades, nanoparticles and nanofibres have demonstrated superior performance in numerous applications, including energy, water, the environment, medicine, and health care etc. [1-4]. However, many of the materials and processes currently used for the synthesis of nanoparticles are dependent on non-renewable resources and also generate hazardous wastes. The potential environmental and health impacts of engineered nanoparticles have been comprehensively studied and reported in the literature [5-8]. Green nanotechnology, the combination of nanotechnology and the principles and practices of green chemistry, may hold the key to building an environmentally sustainable society in the near future. Nanomaterials also offer applications to prevent pollution by utilizing certain catalytic processes to create less waste production, sense pollutants in water and the environment, destroy harmful bacteria and viruses and create clean water and a clean

\footnotetext{
${ }^{1}$ Department of Nanomaterials in Natural Sciences, Centre for Nanomaterials, Advanced Technologies and Innovation, Technical University of Liberec, Studentská 1402/2, Liberec 1, Czech Republic, 46117, phone +420485353017

*Corresponding author: miroslav.cernik@tul.cz
} 
environment [8-10]. Green chemistry is a set of principles or practises that encourages the design of products and processes that reduce or eliminate the use and generation of hazardous substances [11-14]. Current green nanotechnology practices often involve the use of natural sources, non-hazardous solvents, biodegradable and biocompatible materials and energy-efficient processes in the preparation of nanoparticles [15-17].

Remarkable applications of the use of electrospun nanofibres have recently been reported in many fields such as energy, the environment, water purification, sensor devises, tissue engineering scaffolds, wound dressing, drug delivery, etc. [2, 18]. Electrospinning is one of the most proficient and sophisticated methods for the fabrication of nanofibres on a large scale and with a large surface area to volume ratio, high porosity and stability [19]. The electrospinning process parameters such as system and process variable requirements have been meticulously reported in the literature [20, 21]. In order to develop 'green electrospinning' technology it is necessary to use non-toxic, cheap, and environmental friendly solvents and materials. Compared to the current electrospinning process, which utilises hazardous and corrosive and non-ecological organic solvents, water based solvents and polymers are being developed to produce electrospun nanofibres and membranes, which make the electrospinning processes a more economical and greener technology for environmental protection.

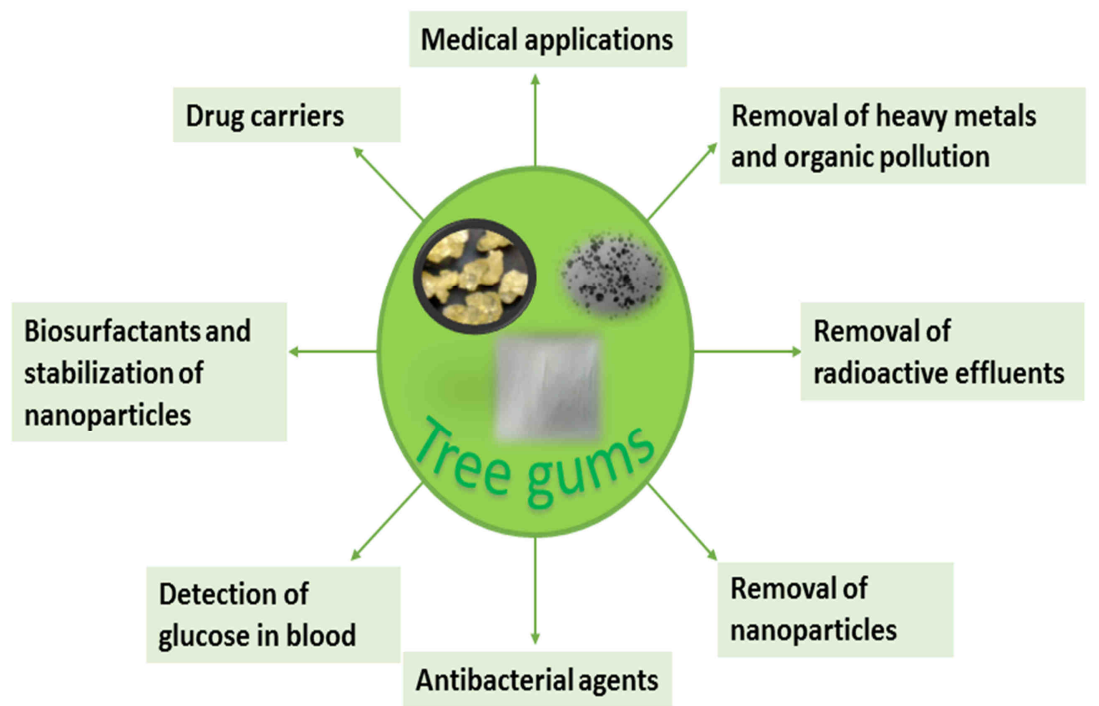

Fig. 1. Non-food applications of tree gums and created with them nanoparticles and nanofibers

In this review, we focus on the green synthesis (fabrication, characterization, and application) of nanoparticles and green electrospinning nanofibres based on tree gum polysaccharides, we also discuss the various fabrication methods using water soluble polymeric blend solutions of gums with polyvinyl alcohol or poly ethylene oxide. Furthermore, the various functionalities of electrospun fibrous membranes, surface modifications and the enhancement of their properties (water contact angle, hydrophobicity/hydrophilicity, fibre diameter, and surface area) before and after various 
plasma treatments (oxygen and methane) are examined. This current report further focuses on our own studies and describes the environmental and antibacterial applications of gum-stabilized nanoparticles, functionalized fibres and membranes. Figure 1 shows the schematic model of the applications of tree gums and created with them nanoparticles and nanofibers.

\section{Natural and renewable sources of reducing agents for the synthesis of nanoparticles}

Nature has created many indispensable materials required for the fabrication of nanoparticles. Among them, plant extracts (Salvia officinalis, Lippia citriodora, Pelargonium graveolens, and Punica granatum), biopolymers (starch, cellulose, chitosan, tree gum polymers), and other natural compounds like vitamins, proteins, peptides (e.g. glutathione), and sugars (e.g. glucose, fructose) are such materials, which provide suitable reducing and surface agents for the nanoparticle synthesis/stabilization [14-17, 22-30]. Plant extracts are regarded as one of the most promising natural reducing agents, such as metabolities (e.g. sugars, alkaloids, polyphenols, phenolic acids terpenoids), and proteins and co-enzymes help to synthesis metal and metal oxide nanoparticles [31-37]. These NPs can be used in biomedical applications due to their production advantages via a biosynthetic route, which fashions the defined size, morphology and high chemical purity of NPs [38].

Biopolymers (cellulose and its derivatives, chitosan and its derivatives, alginate, dextran, and tree gums) are another family of natural sources used as reducing and stabilizing agents for metal and metal oxide nanoparticle synthesis [39-58]. Vitamin $\mathrm{B}_{1}$, Vitamin $B_{2}$ (riboflavin), Vitamin $C$ (ascorbic acid), coffee and tea extracts, beet juice, and grape pomace are well-known natural reducing agents or antioxidants used for the synthesis of stable nanoparticles and are comprehensively reported [59-65].

\section{Tree gums - an overview}

Gums are hydrocolloids, which are hydrophilic in nature and are found in almost every biosphere on earth; in plants, animals, and many bacteria. They contain a large number of hydroxyl groups, usually arranged in a fairly regular manner along the backbone of the molecule, which allows for the chelation of mono- and divalent cations, thereby cross-linking the hydrocolloid chains together and forming complex macrostructures [66-68]. Hydrocolloids are some of the most well-known polysaccharides, having complex structures with glycosidic bonding. Most gums are heterogeneous polysaccharides with complicated structures and extremely high molecular masses [69-71]. The simplest interactions of hydrocolloids are (as the name suggest) with water and it is this interaction that is key to their use in foodstuffs. Gum hydrocolloids are effective water adsorbents and to a greater or lesser extent may be solubilized by water. Owing to the high number of hydroxyl groups, water is held within the molecular structure by hydrogen bonding and also within the voids created by the complex molecular configuration [72-76]. The important tree exudate gums available on the market are gum arabic (GA), gum karaya (GK), gum tragacanth (GT), kondagogu gum (KG), and gum ghatti (GG). Extensive research has been carried out on various aspects of these tree gum polysaccharides, which includes their availability, molecular weight distribution, chemical structures, and food \& non-food 
applications [77-80]. None of the three gums are produced in developed countries. They must be imported from developing countries. The chemical composition of these gums is complex and varies depending on the source and its age. Therefore, it is not possible to provide defined structural formulas of these biopolymers. Exudate gums are used in an overwhelming number of applications, especially in the food industry. However, there are also considerable non-food applications [78].

Gum arabic (GA) is a branched, neutral or slightly acidic, complex polysaccharide obtained as a mixed calcium, magnesium, and potassium salt. The backbone consists of $1 \rightarrow 3$-linked $\beta$-D-galactopyranosyl units. The side chains are composed of two to five $1 \rightarrow 3$-linked $\beta$-D-galactopyranosyl units, joined to the main chain by $1 \rightarrow 6$-linkages. Both the main and the side chains contain units of $\alpha$-L-arabinofuranosyl, $\alpha$-L-rhamnopyranosyl, $\beta$-D glucuronopyranosyl, and 4- $O$-methyl- $\beta$-D-glucuronopyranosyl units, the latter two mostly as end-units [81-83]. It is suggested that the high-molecular-weight fraction of the gum consists of large carbohydrate blocks with a molecular mass of approximately $2.5 \cdot 10^{5} \mathrm{Da}$ attached individually to a polypeptide chain. GA is obtained from the stems and branches of Acacia Senegal and Acacia seyal, and being a branched polysaccharide, it exhibits unique structural, physical and chemical properties [84-87]. Consequently, it is widely used in food and pharmaceutical applications [88-90].

Gum tragacanth (GT) is a complex, highly branched, heterogeneous polysaccharide, naturally occurring as a slightly acidic calcium, magnesium, and potassium salt. It has a molecular mass of approximately $8.4 \cdot 10^{5} \mathrm{Da}[91,92]$. The composition of the gum obtained from different Astragalus species shows considerable variation. This variability is not surprising, since the genus Astragalus is the largest within the Leguminosae family. It occurs worldwide in tropical regions and contains around 2,000 species, grouped into more than 100 sub-divisions [93]. GT consists of two fractions; tragacanthic acid or bassorin is insoluble in water, but has the capacity to swell and form a gel, and the other fraction is called tragacanthin and is water-soluble. Both fractions contain small amounts of proteinaceous material and methoxyl groups, the latter being present in higher amounts in the water-soluble fraction [94]. The water-swellable tragacanthic acid fraction has a high molecular weight and a rod-like molecular shape. The main chain is formed by 1,4-linked D-galactose residues with side chains of D-xylose units attached to the main chain by 1,3 linkages. The water-soluble tragacanthin is a neutral, highly branched arabino-galactan with a spherical molecular shape. Its structure probably consists of a core composed of 1,6- and 1,3-linked D-galactose with attached chains of 1,2-, 1,3-, and 1,5-linked L-arabinose $[75,95]$. GT is mainly used in food and pharmaceutical fields.

Gum karaya $(\mathrm{GK})$ is a complex, partially acetylated polysaccharide obtained as a calcium and magnesium salt. It has a branched structure and a high molecular mass of approximately $16 \cdot 10^{6} \mathrm{Da}[96,97]$. The backbone of the gum consists of $\alpha$-D-galacturonic acid and $\alpha$-L-rhamnose residues. Side chains are attached by 1,2-linkage of $\beta$-D-galactose or by 1,3-linkage of $\beta$-D-glucuronic acid to the galacturonic acid of the main chain. Furthermore, half of the rhamnose residues of the main chain are 1,4-linked to $\beta$-D-galactose units $[92,98,99]$. The chemical composition of gum samples obtained from different Sterculia species and from different places of origin was found to be quite similar $[96,100]$. Commercial gum karaya contains approximately $13-26 \%$ galactose and $15-30 \%$ rhamnose, which is considerably higher than the rhamnose content of other commercial exudates gums [100]. However, the protein content of approximately $1 \%$ is lower than that 
of other exudate gums. Gum karaya contains approximately $40 \%$ uronic acid residues and $8 \%$ of acetyl groups [98]. Due to the presence of these acetyl groups; native gum karaya is insoluble and only swells in water. Le Cerf et al [97] distinguished three fractions in gum karaya, based on their solubility in water. Only $10 \%$ of the native gum was solubilized in cold water, increasing to $30 \%$ in hot water. After deacetylation with dilute ammonia, $90 \%$ of the native gum dissolves in water. The equivalent weight of the deacetylated-soluble fraction was higher than that of the cold-water-soluble fraction. This indicates that only lower-molecular-weight molecules are able to dissolve in cold water, while deacetylation leads to the solubilisation of material of a higher molecular weight $[78,97]$.

a)

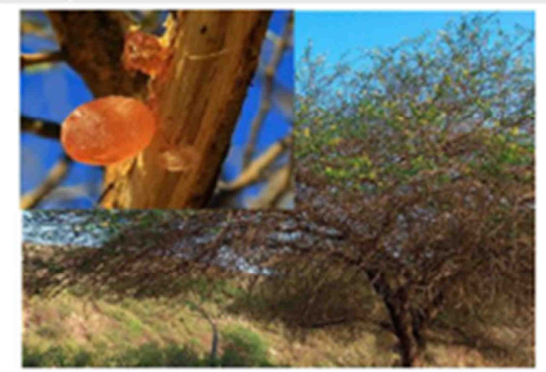

GA tree and production of gums

c)

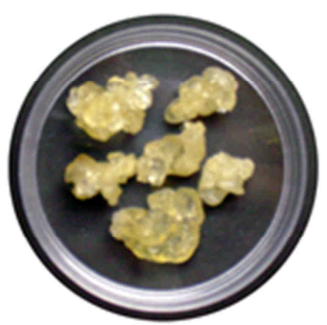

Specimen of KG

e)

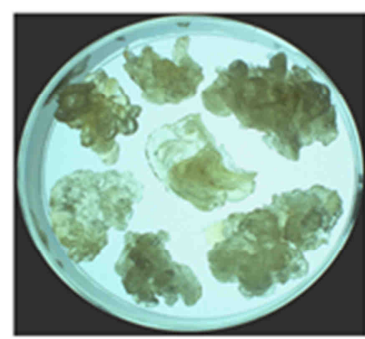

Specimen of GK b)

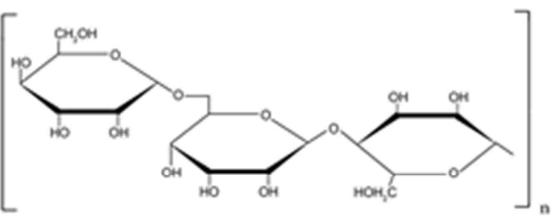

Partial chemical structure of GA

d)

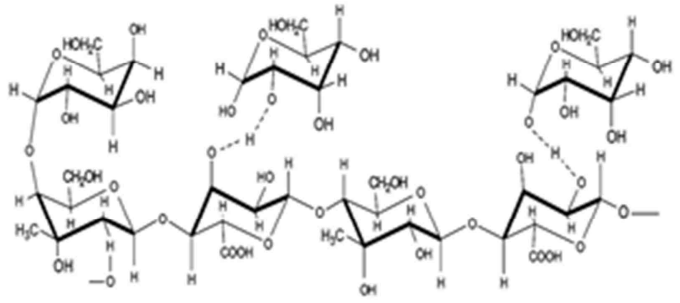

Partial chemical structure of KG

f)

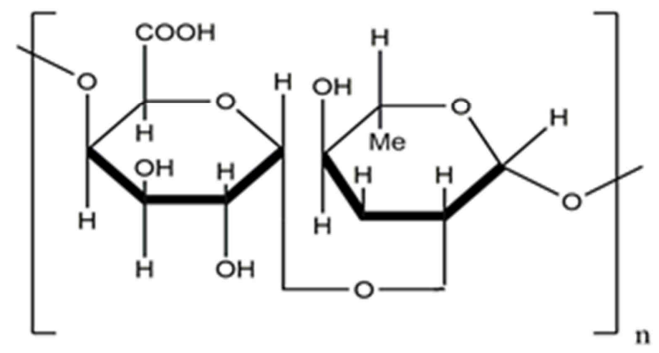

Partial chemical structure of GK

Fig. 2. Specimens of: a) GA, c) KG, and e) GK with their corresponding partial chemical structures (b, d, and f, respectively) [79] 
Gum kondagogu (KG) belongs to the species of Cochlospermum and family Bixaceae. Even though gum karaya, also known as Indian tragacanth, and KG are classified in the same group, there are considerable differences in their physical and chemical properties $[101,102]$. Extensive research has been carried out on KG (Cochlospermum gossypium), a gum extracted from kondagogu tree, which grows in India, including its morphological, physical and chemical, structural, rheological, pharmaceutical emulsifying properties and its toxicological evaluation as a food additive [79, 80, 102-107]. Furthermore, this gum can also be used as a biosorbent for the removal of toxic metal contaminants from aqueous environments and also as an environmental friendly material for the stabilization and a reducing agent for the synthesis of metal/metal oxide nanoparticles [108-112]. Structural analysis of this biopolymer has shown that it contains sugars such as arabinose, rhamnose, glucose, galactose, mannose, glucuronic acid and galacturonic acid. Based on spectroscopic characterization, the probable structural feature assigned to KG is $(1 \rightarrow 2) \beta$-D-Gal $p$, $(1 \rightarrow 6) \beta$-D-Gal $p,(1 \rightarrow 4) \beta$-D-Glc $p$ A, 4-0-Me- $\alpha$-D-Glc $p$ A, $(1 \rightarrow 2) \alpha$-L-Rha, and $(1 \rightarrow 4) \alpha-D-G a l p$ A $[79,80]$.

Gum ghatti (GG), an Indian gum, is a non-starch polysaccharide, and the main species is Anogeissus latifolia (Combretaceae, Myrtales), a large deciduous tree found in dry areas $[113,114]$. GG is used as an emulsifier and thickener in food industries [115-117]. Recently, Deshmukh et al [118] reported a detailed review of the molecular structure, properties, and pharmaceutical applications of GG.

\section{Tree gums as a natural renewable source for the green synthesis of nanoparticles}

Tree gums (GA, GK, KG, GT, and GG) have been used as a template for the synthesis and stabilization of various metal $\left(\mathrm{Ag}, \mathrm{Au}, \mathrm{Pt}, \mathrm{Pd}, \mathrm{Fe}, \mathrm{Cu}\right.$, Se etc.) and metal oxide $\left(\mathrm{Fe}_{3} \mathrm{O}_{4}\right.$, $\mathrm{CuO}, \mathrm{ZnO}$ etc.) nanoparticles [27, 28, 58, 65, 124, 119-139].

All of the above-mentioned NPs (Table 1) were characterized using a variety of spectroscopic and microscopic analyses, such as UV-visible spectrophotometry, scanning electron microscopy (SEM), transmission electron microscopy (TEM), Fourier transform infrared spectroscopy (FTIR), powder X-ray diffraction (XRD) and energy dispersive spectroscopy (EDS). Vinod et al [131] reported that the colloidal NPs with average sizes of $\mathrm{Ag}(5.5 \pm 2.5 \mathrm{~nm}), \mathrm{Au}(97.8 \pm 2.3 \mathrm{~nm})$ and Pt $(2.4 \pm 0.7 \mathrm{~nm})$ stabilized with KG were found to be stable even after 6 months at room temperature, and the reduction was attributed to the various functional groups $\left(-\mathrm{OH},-\mathrm{COO},-\mathrm{C}=\mathrm{O}\right.$, and $\left.\mathrm{CH}_{3} \mathrm{CO}-\right)$ present in the gum structure. Furthermore, gums have three major parameters for the preparation of NPs and follow the cardinal principles of green chemistry; i.e. the environmentally benign solvent medium (water and ionic liquid-based green solvents) for the synthesis of NPs; gum acts as reducing agent due to the presence of many functional groups in the gum structure $(-\mathrm{OH}$, - $\mathrm{COO}-,-\mathrm{CO}$, and $\mathrm{CH}_{3} \mathrm{CO}-$ ) and gums are non-toxic and biodegradable materials for the stabilization of NPs. However, even today, many studies have reported the use of toxic solvents such as organic solvents, and toxic, highly reactive and environmentally and biologically risky reducing agents such as hydrazine, sodium borohydride and dimethyl formide, and capping agents such as EDTA, triethanolamine and tetraethylammonium bromide, which are known to bio-accumulate in the environment and are persistent pollutants, which may have ecological or human health risks, used for the synthesis of NPs $[8-10,17]$. 
Synthesis of metal and metal oxide NPs interceded by various tree gum polysaccharides

\begin{tabular}{|c|c|c|c|}
\hline Tree gums & Type of NPs & Size, morphology and stability of NPs & References \\
\hline Gum arabic (GA) & $\mathrm{Ag}$ & $\begin{array}{l}\sim 5 \mathrm{~nm} \text {; face centred cubic structures with crystalline, } \\
5 \text { month stability }\end{array}$ & [119] \\
\hline GA & $\mathrm{Ag}$ & $16.0 \pm 2.0$ n.m; FCC, highly stable & {$[120]$} \\
\hline GA & $\mathrm{Ag}$ & $\begin{array}{l}\text { 2-20 nm; spherical shape, single crystalline, highly } \\
\text { stable for one month }\end{array}$ & [121] \\
\hline GA & $\mathrm{Au}$ & $6.52 \pm 0.66 \mathrm{~nm}$, spherical, stable for 5 weeks & [122] \\
\hline GA & $\mathrm{Au}$ & $5.5 \mathrm{~nm}$, with spherical particles; crystalline & [123] \\
\hline GA & $\mathrm{Au}$ & $\begin{array}{l}26.8 \pm 5.3 \mathrm{~nm} \text {, with FCC structures, spherical, } \\
\text { stable even in the presence of } \mathrm{NaCl} \text { up to } 3 \mathrm{M}\end{array}$ & {$[27]$} \\
\hline GA & $\mathrm{Au}$ & $15-20 \mathrm{~nm}$, spherical & [124] \\
\hline $\mathrm{GA}-\mathrm{Fe}_{3} \mathrm{O}_{4}$ & $\mathrm{Au}$ & $2 \mathrm{~nm}$, spherical & {$[65]$} \\
\hline GA & $\mathrm{Se}$ & $\sim 34.9 \mathrm{~nm}$, with spherical structures & [28] \\
\hline GA & $\mathrm{Cu}$ & $\begin{array}{l}\sim 3-9 \mathrm{~nm} \text {, with spherical particles; } \\
\text { crystalline structure }\end{array}$ & {$[125]$} \\
\hline GA & $\mathrm{Fe}_{3} \mathrm{O}_{4}$ & $\sim 20 \mathrm{~nm}$, with non-spherical morphology & [126] \\
\hline Gum karaya (GK) & $\mathrm{Ag}$ & $\begin{array}{c}12.5 \pm 2.5 \mathrm{~nm} \text {, spherical particles, crystalline and } \\
\text { stable for } 6 \text { months }\end{array}$ & {$[58]$} \\
\hline GK & $\mathrm{Ag}$ & $4 \pm 2 \mathrm{~nm}, \mathrm{FCC}$ with crystalline structure & {$[127]$} \\
\hline GK & $\mathrm{Ag}$ & $7-10 \mathrm{~nm}$, spherical & [128] \\
\hline GK & $\mathrm{Au}$ & $7.8 \pm 1.8 \mathrm{~nm}$, spherical, stabile for 6 months & {$[58]$} \\
\hline GK & $\mathrm{Au}$ & $20-25 \mathrm{~nm}$, spherical & [129] \\
\hline GK & $\mathrm{Pt}$ & $5.0 \pm 1.2 \mathrm{~nm}$, spherical & {$[58]$} \\
\hline GK & $\mathrm{CuO}$ & $10.5 \pm 2.4 \mathrm{~nm}$, spherical & {$[130]$} \\
\hline GK & $\mathrm{Fe}_{3} \mathrm{O}_{4}$ & $18.5 \pm 3.5 \mathrm{~nm}$, spherical & {$[58]$} \\
\hline $\begin{array}{l}\text { Gum kondagogu } \\
(\mathrm{KG})\end{array}$ & $\mathrm{Ag}$ & $\begin{array}{l}5.5 \pm 2.5 \mathrm{~nm} \text {, spherical, FCC, stable for more than } \\
6 \text { months }\end{array}$ & {$[131]$} \\
\hline KG & $\mathrm{Ag}$ & $3 \mathrm{~nm}$, spherical, highly stable & [132] \\
\hline KG & $\mathrm{Au}$ & $\begin{array}{l}7.8 \pm 2.3 \mathrm{~nm} \text {, spherical, stable for more than } \\
6 \text { months }\end{array}$ & {$[131]$} \\
\hline KG & $\mathrm{Au}$ & $12 \pm 2 \mathrm{~nm}$, nano-crystalline & {$[133]$} \\
\hline KG & $\mathrm{Pt}$ & $\begin{array}{l}2.4 \pm 0.7 \mathrm{~nm} \text {, crystalline, stable for more than } \\
6 \text { months }\end{array}$ & {$[131]$} \\
\hline KG & $\mathrm{Fe}_{3} \mathrm{O}_{4}$ & $\begin{array}{l}\text { spherical size iron oxide particles with diameters } \\
\text { in the range of } 8-15 \mathrm{~nm}\end{array}$ & {$[134]$} \\
\hline $\begin{array}{l}\text { Gum tragacanth } \\
(\mathrm{GT})\end{array}$ & $\mathrm{Ag}$ & $13.1 \pm 1.0 \mathrm{~nm}$ with spherical nanoparticles & {$[135]$} \\
\hline GT & $\mathrm{ZnO}$ & $\begin{array}{l}55-80 \mathrm{~nm} \text {, high crystalline nature and single phase } \\
\text { of synthesized }\end{array}$ & [136] \\
\hline Gum ghatti (GG) & $\mathrm{Ag}$ & $5.7 \pm 0.2 \mathrm{~nm}$, spherical nanoparticles & [137] \\
\hline GG & $\mathrm{Pd}$ & $4.8 \pm 1.6 \mathrm{~nm}$, spherical shape & {$[138]$} \\
\hline GG & $\mathrm{Fe}_{3} \mathrm{O}_{4}$ & $35 \mathrm{~nm}$ & [139] \\
\hline
\end{tabular}

Figures 3 and 4 show the various nanoparticles $\left(\mathrm{Ag}, \mathrm{Au}, \mathrm{Pt}, \mathrm{Fe}_{3} \mathrm{O}_{4}, \mathrm{CuO}\right)$ synthesised using $\mathrm{GK}$ and $\mathrm{KG}$. 

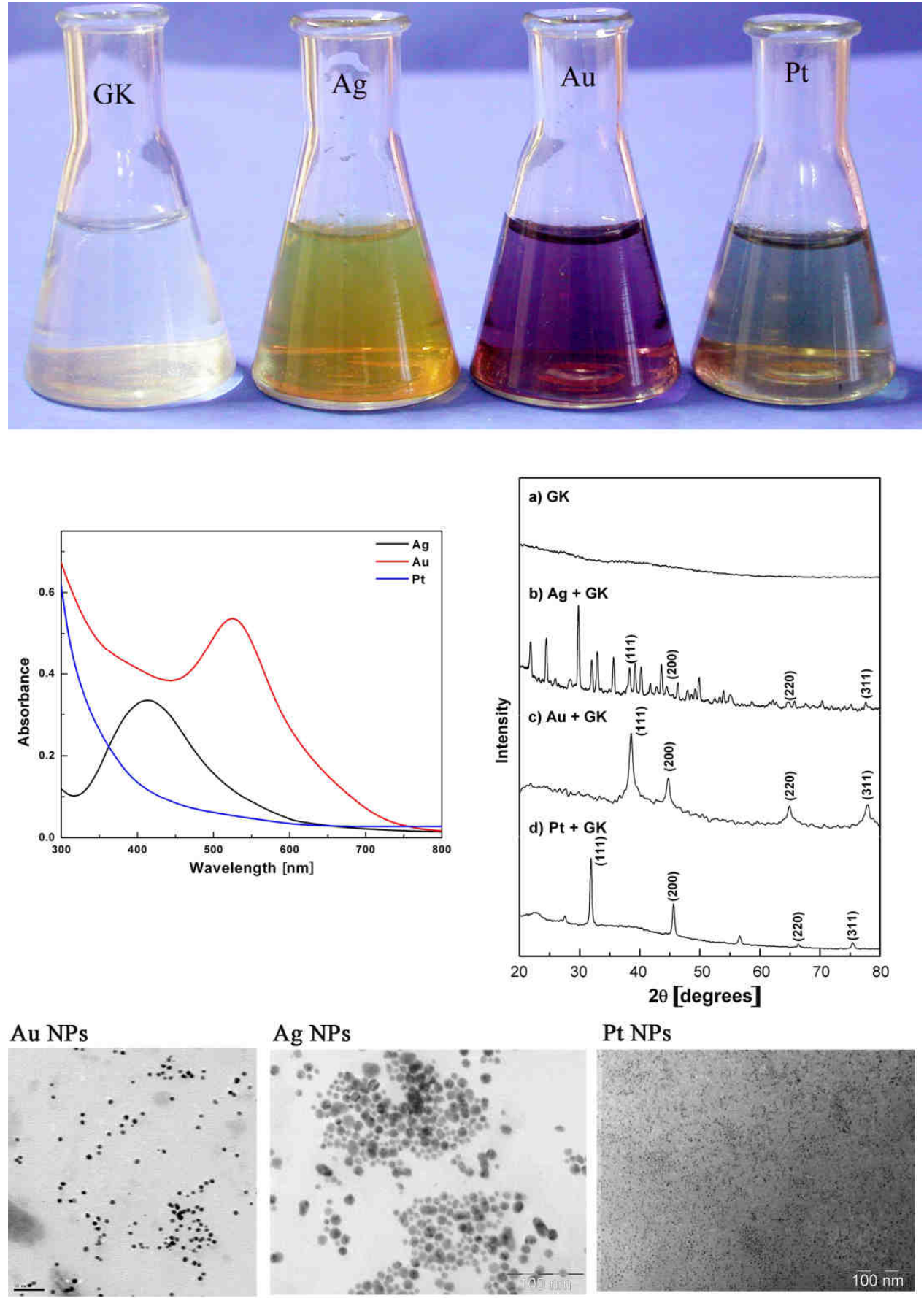

Pt NPs

Fig. 3. Striking colours of NPs (Ag, Au, and Pt) synthesised using KG as reducing and stabilizing agent (panel 1); UV-VIS and XRD spectral analysis of NPs (panel 2); and TEM pictures of NPs (panel 3) 

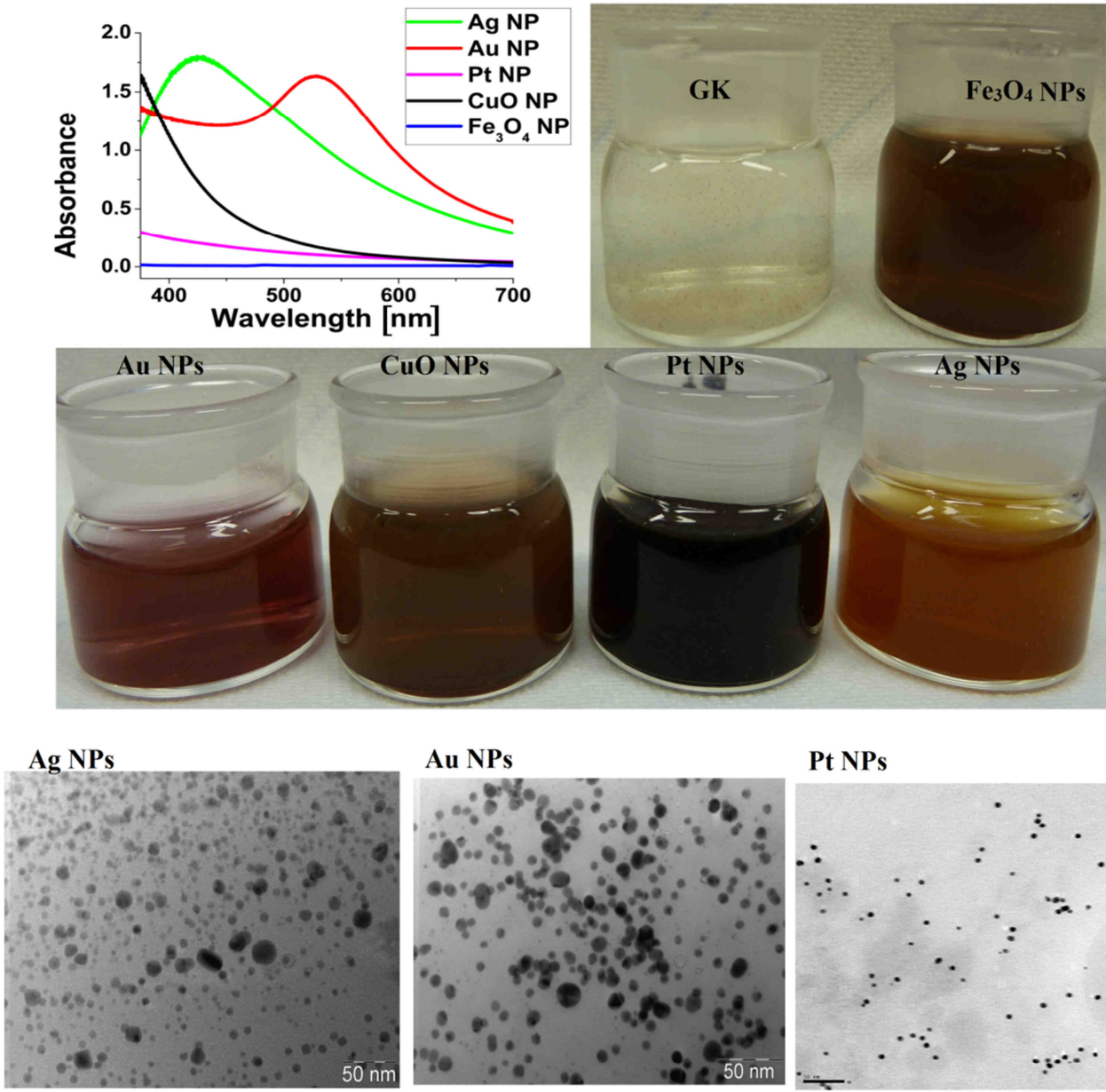

Au NPs

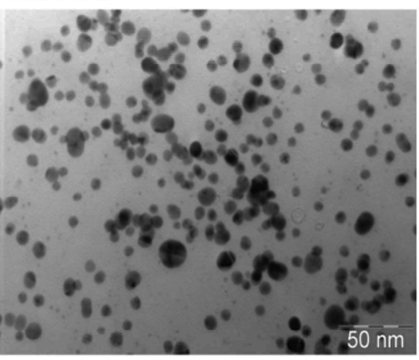

Pt NPs

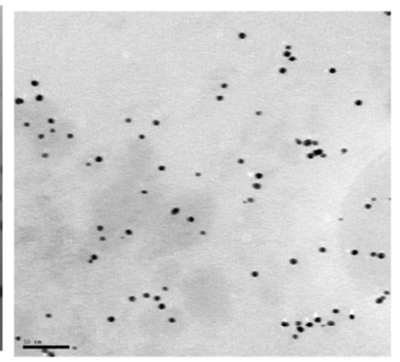

\section{CuO NPs}

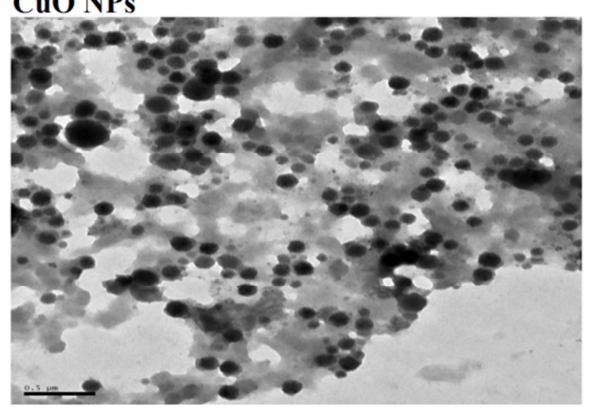

\section{$\mathrm{Fe}_{3} \mathrm{O}_{4} \mathrm{NPs}$}

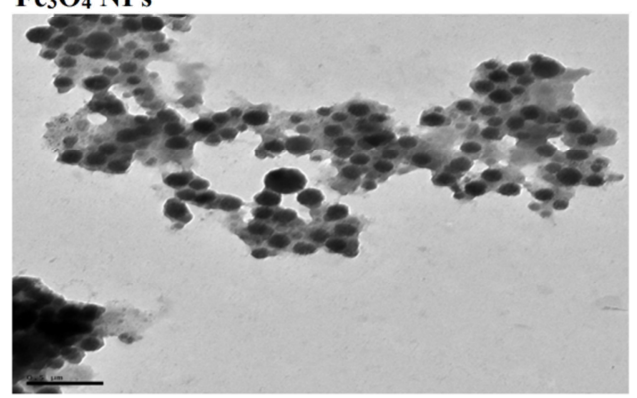

Fig. 4. NPs synthesized using GK; UV-VIS spectral analysis of NPs; showing the formation various synthesized NPs ( $\mathrm{Ag}, \mathrm{Au}, \mathrm{Pt}, \mathrm{Fe}_{3} \mathrm{O}_{4}$, and $\left.\mathrm{CuO}\right)$; and TEM analysis of NPs 


\section{“Green” electrospinning based on tree gums}

Fibres produced by electrospinning have been known for over ninety years, when the Czech-American physicist John Zeleny studied techniques known today as electrospinning and electrospraying. When a conductive liquid in a capillary is exposed to an electric field in a range of $\sim 10 \mathrm{kV}$, the liquid shape forms a cone, which emits a jet of liquid. Fibres are formed by the solution drying during flight to the opposite electrode (collector). Industrial production based on roller electrospinning was developed by Oldrich Jirsak, professor of TUL, in the Czech Republic in 2004. Nowadays, sub-micron fibres and nanofibres can be formed from solutions and melts, from various chemicals and material mixtures, from traditional or "green" materials, in a DC or AC field, and with a core-shell structure of two different materials, etc. Similar to the broad spectrum of fibre types, the potential for their application is even broader and includes mechanical engineering, optics, electronics, medicine and drug production, biotechnologies, environmental protection etc.

The development of electrospun fibres and membranes based on natural renewable materials for energy and environmental applications is still underway. "Green" electrospinning technology relies on the development of non-toxic, inexpensive and environmentally friendly polymers and solvents (such as water or ionic solvents) for the fabrication of electrospun fibres and membranes. Electrospun natural biodegradable polymers have shown great applicability in many fields such as the development of filtration membranes, catalytic nanofibres, tissue engineering, drug delivery and sensors $[140,141]$. The application of electrospun nanofibres in the area of biomedicine, drug delivery, tissue engineering, wound dressing, water purification, and energy has been reported [142-144]. Electrospun nanofibres from natural tree gum based bio-polymers are an innovative group of economic and environmentally friendly membranes for the potential applications in energy, environmental and biomedical fields.

Natural biopolymers such as Chiton, chitosan, gum tragacanth, and guar gum blended with synthetic biocompatible polymers (PVA or PEO) have been reported to be suitable for producing electrospun membranes [145-150]. Very recently, natural tree polymers such as GA, GK, and KG have undergone electrospinning and the system and process parameters have been standardised to produce smooth and uniform nanofibres [151-155]. Furthermore, many combinations of tree gums have been blended with PVA or PEO and the solubility of the polymer has been determined to subsequently improve the spinnability, solubility, biocompatibility, biodegradability, and mechanical properties of the electrospun membranes. In addition, chemical modifications of natural polymers, with DDSA or Ag NPs to develop the antibacterial membranes have also been reported [152].

\section{Electrospun fibres and membranes of GA, GK, and KG}

As reported by Padil et al [151, 152, 154, 155], aqueous PVA (10-12 wt. \%) was mixed with GA, GK, and KG solutions (varying from 2 to 5 wt. \%) in different weight proportions of PVA or PEO with GA, GK, and KG (100/0, 50/50, 60/40, 70/30, 80/20, $90 / 10$ and 0/100), to determine the good spinnability and uniform size of nanofibres after electrospinning. The electrospinning is carried out on a Nanospider electrospinning machine (Elmarco, NS IWS500U, Liberec, Czech Republic) with interchangeable electrode systems, working with both water or non-water soluble polymers. The details of the electrospinning conditions are as follows: spinning electrode width of $500 \mathrm{~mm}$, effective nanofibre layer width of 200-500 mm; spinning distance of $130-280 \mathrm{~mm}$, substrate speed of 
$0.015-1.95 \mathrm{~m} / \mathrm{min}$, voltage of $0-55 \mathrm{kV}$ and process air flow of $20-150 \mathrm{~m}^{3} / \mathrm{h}$. The ratios of the best combinations of the blend mixtures of gum were as follows: PVA was found to have a 30:70 to 10:90 ratio of gum/PVA in the final electrospinning mixture. The SEM and TEM images of GA, GK, and KG with their electrospun fibres and plasma treated fibres are presented in Figures 5, 6, and 7, respectively.

a)

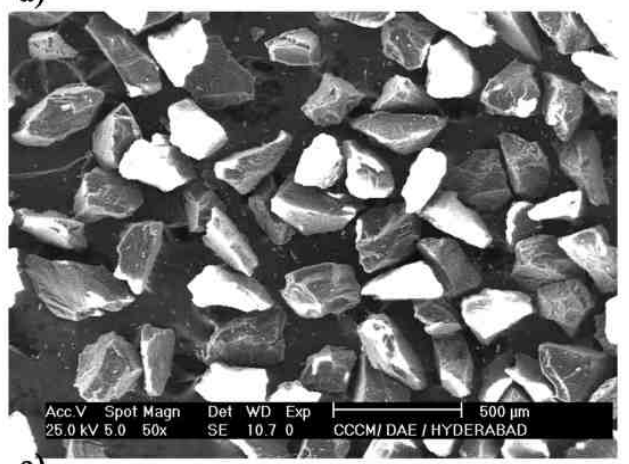

c)
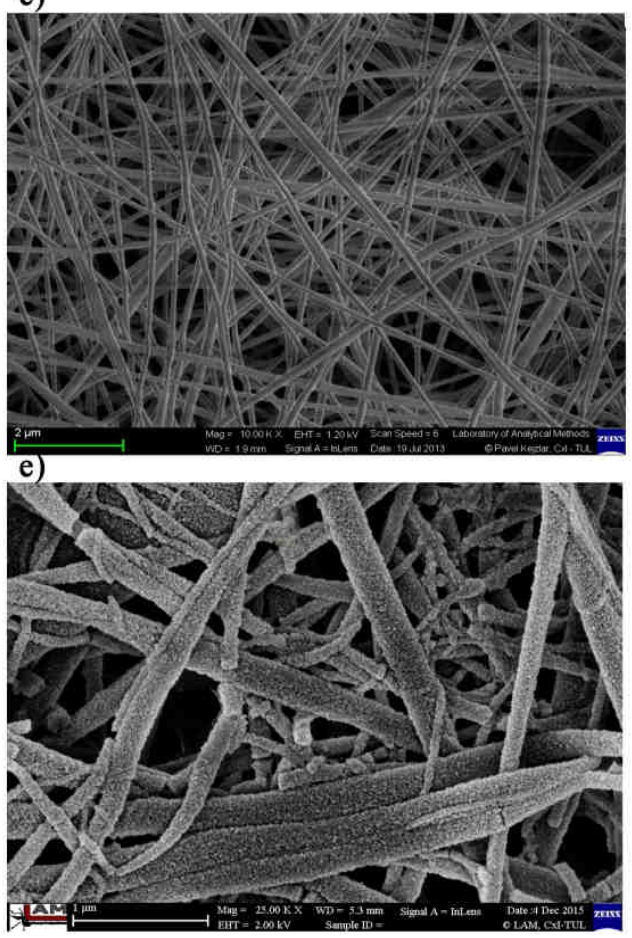

b)

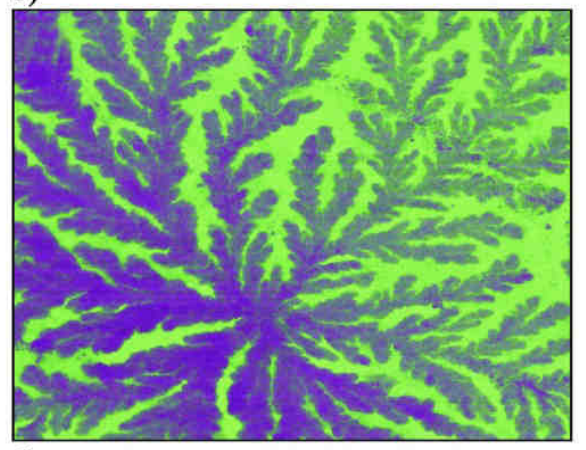

d)

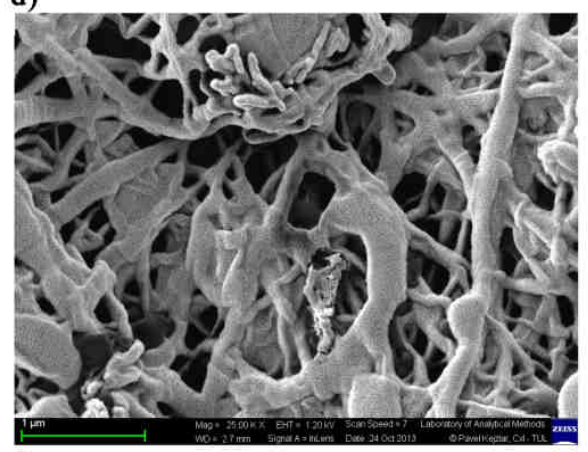

f)

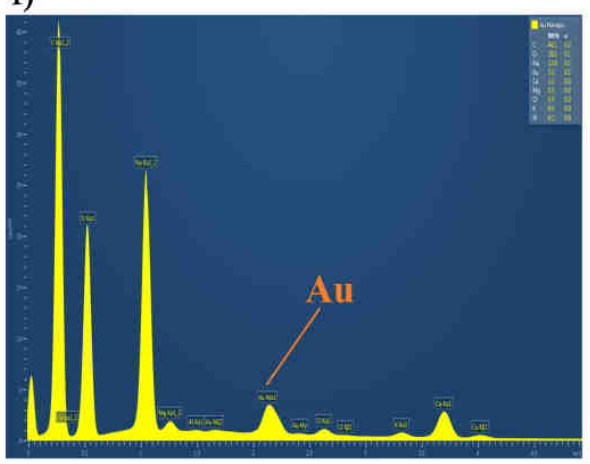

Fig. 5. SEM photographs of KG showing irregular particle sizes (a); TEM analysis of KG showing network molecular structure (b); electrospun fibres of KG (c); plasma treated membranes of KG (d); Au NP adsorbed on fibres of KG (e); EDX analysis of Au adsorbed structures of KG (f) 
a)

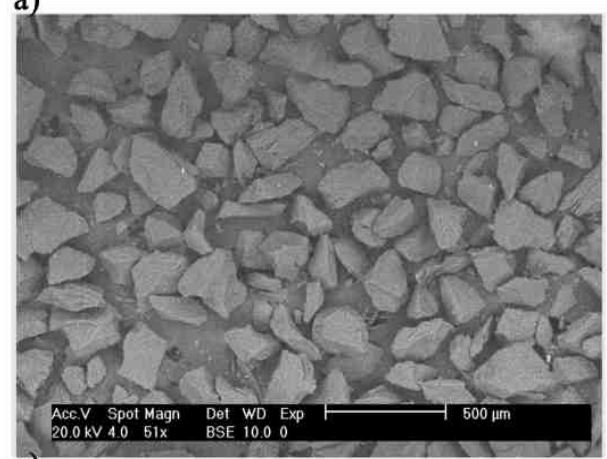

c)

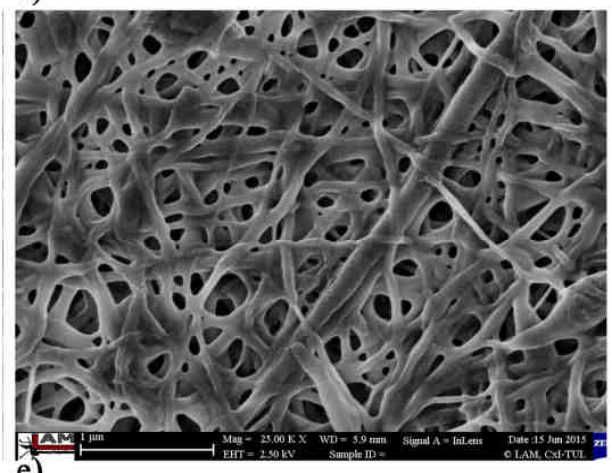

e)

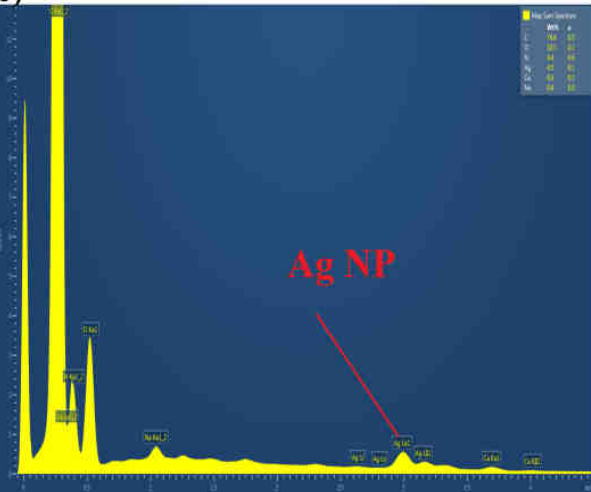

b)

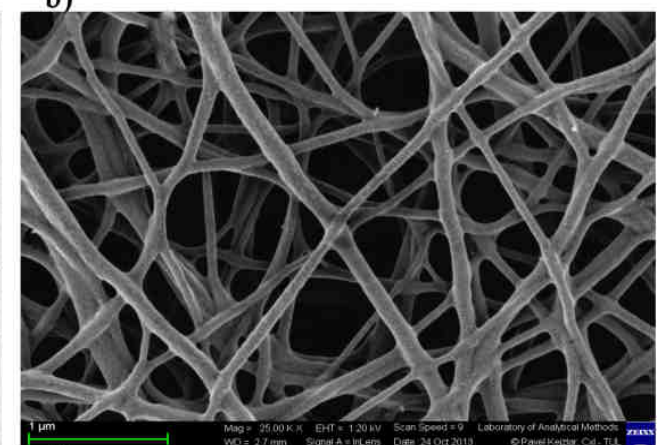

d)

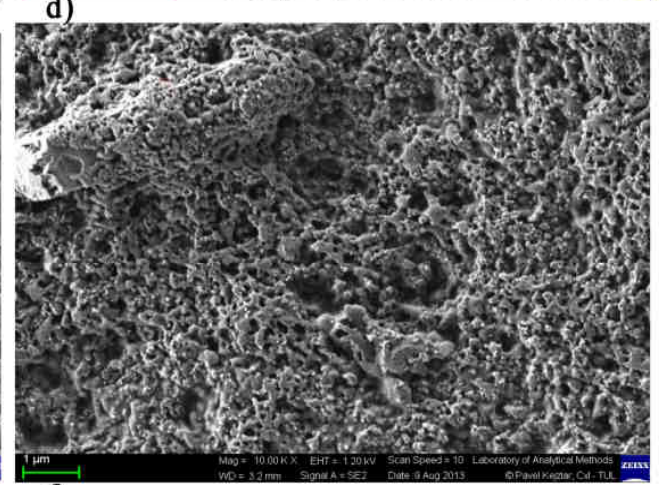

f)

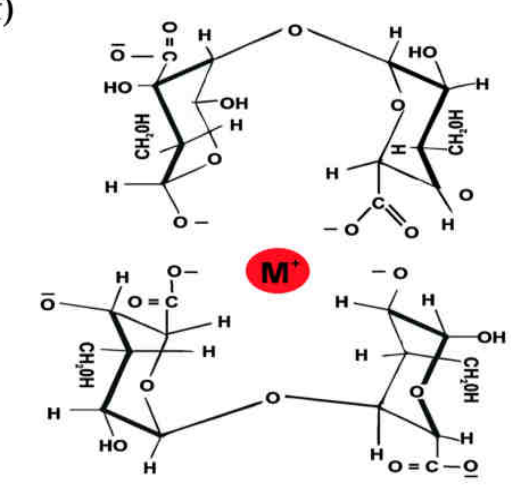

Fig. 6. SEM picture of GK showing the irregular particle sizes (a); electrospun fibres of GK (b); plasma treated membranes of GK (c); Ag adsorbed membranes of GK (d); EDX analysis of Ag NPs adsorbed membrane (e); schematic interpretation of metal ion interaction with GK structure (f) 
a)

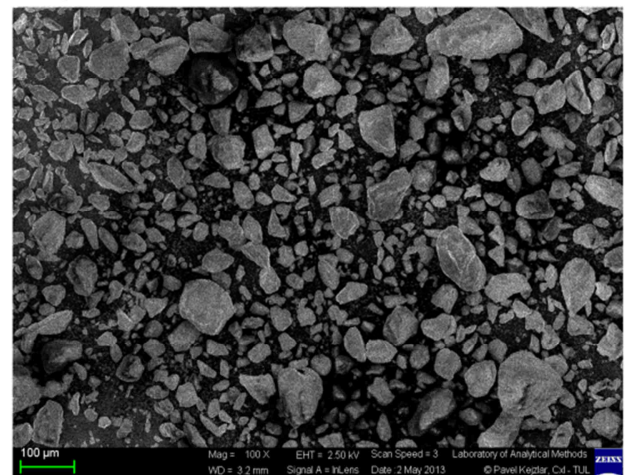

c)

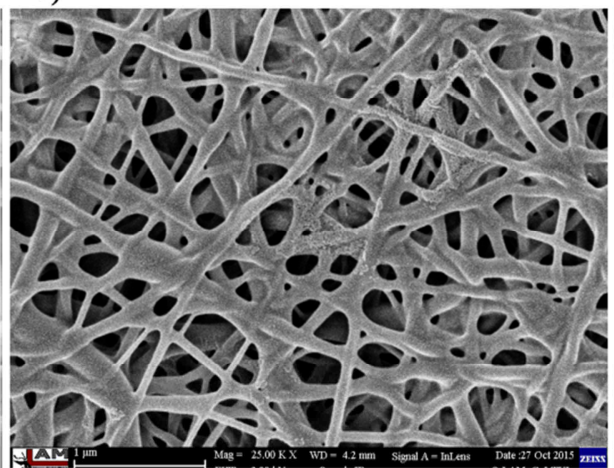

e) b)

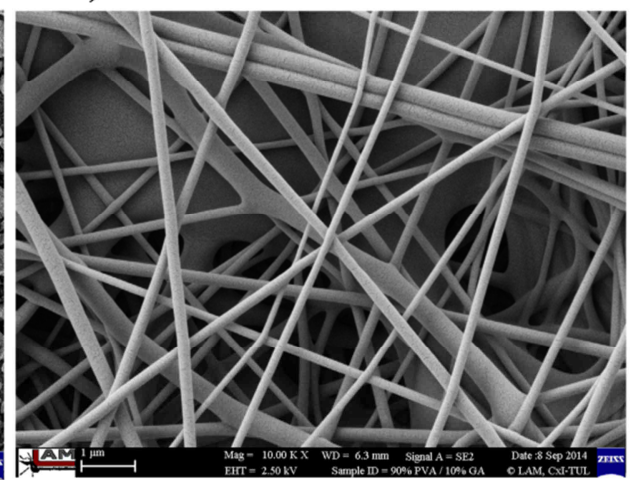

d)

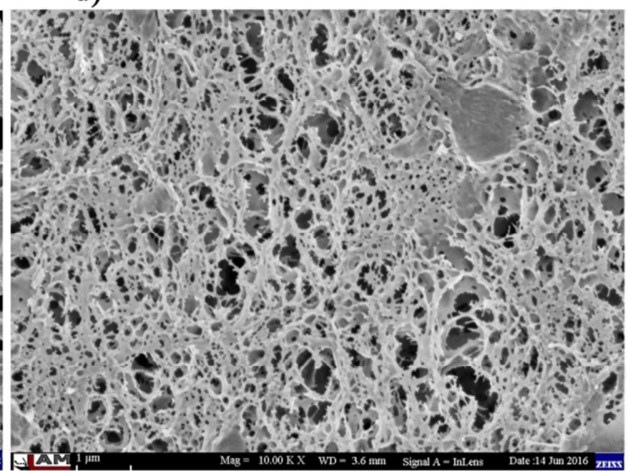

f)

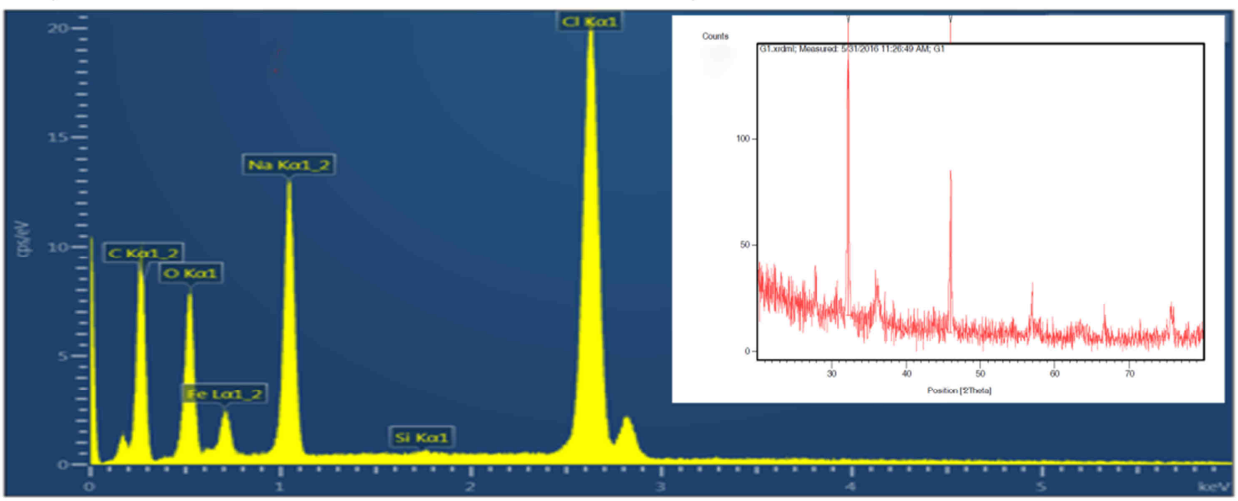

Fig. 7. SEM pictures of GA indicating the different range of particles sizes (a); electrospun membranes of GA (b); plasma treated membranes of GA (c); Adsorption of $\mathrm{Fe}_{3} \mathrm{O}_{4}$ onto GA electrospun membranes (d); EDX analysis showing Fe traces on the $\mathrm{GA}-\mathrm{Fe}_{3} \mathrm{O}_{4}$ membranes (e); XRD patterns of $\mathrm{Fe}_{3} \mathrm{O}_{4}$ observed in $\mathrm{GA}-\mathrm{Fe}_{3} \mathrm{O}_{4}$ membranes (f) 


\section{Membrane treatments and characteristics}

\section{Plasma treatment}

Plasma-surface modification is an efficient and cost-effective surface treatment technique used in biomedical research such as sputtering and etching, implantation, deposition, polymerization, spraying, and laser plasma deposition [156]. The unique advantage of plasma modification is that the surface properties and biocompatibility can be significantly altered, while the bulk qualities of the materials remain unchanged [157]. Various gas plasma treatment methods (oxygen, argon, and methane) have been developed to modify the surface properties of polymers, such as the balance of hydrophilicity/hydrophobicity and surface free energy [158]. Typically, plasma treatment modifies the surface by grafting hydroxyl $(-\mathrm{OH})$, carbonyl $(-\mathrm{CO})$, and carboxylate $(-\mathrm{COOH})$ groups [159-162]. Through the processes of plasma modification, it is possible to influence the change of the wettability and water contact angle either to strongly hydrophilic or more hydrophobic, depending upon the nature of the plasma used for the modification and the plasma treatment time [162-165]. As it is stated in the literature, the treatment of membranes using various gas plasma treatment methods such as oxygen, argon, nitrogen has been developed to modify the hydrophilic surface properties of polymers $[165,166]$. However, methane or sulphur hexafluoride plasma treatment on various polymeric membranes is used to enhance the hydrophobicity of the polymer surfaces, resulting in higher contact angles [167, 168].

The GA, GK, and KG fibres were treated with methane plasma to improve their hydophobility, stability, water contact angle and surface area [151, 152, 154]. The methane plasma treated membrane was prepared in a $13.56 \mathrm{MHz}$ radio frequency (RF) plasma reactor (BalTec Maschinenbau AG, Pfaffikon, Switzerland). The plasma chamber was thoroughly purged with a continuous flow of the gas used during the treatment to reduce trace amounts of air and moisture. During the treatment, the gas flow was adjusted in order to keep a constant pressure of $20 \mathrm{~Pa}$ inside the chamber. The plasma conditions and process parameters were as follows: voltage of $300 \mathrm{~V}$; power $20 \mathrm{~W}$; time of 5 minutes; plasma gas purity of $99.997 \%$; electrode area of $48 \mathrm{~cm}^{2}$; inter-electrode distance of $50 \mathrm{~mm}$, and chamber volume of $1,000 \mathrm{~cm}^{3}$.

\section{Cross-linking and stability of electrospun fibres}

Heat and plasma treatments were conducted on the fibres and membranes for their application in environmental remediation and antibacterial fields. The GA, GK, and KG membranes are heated to $130-150^{\circ} \mathrm{C}$ and their stability was tested against an acid, alkaline and aqueous solution, and it was determined that all of the heat-treated membranes were stable up to $90-95 \%$ under all of these tested conditions [151-154]. Subsequently, the water contact angle $(\theta)$, membrane thickness, porosity, apparent density, BET surface area and degree of stability were found to have increased after methane plasma modification [151-154]. Figure 5 presents the morphological changes that occurred due to the plasma treatments on the tree gums. 


\section{Applications of electrospun nanofibres for environmental bioremediation}

The simplicity of the fabrication scheme, the diversity of materials suitable for use with electrospinning, as well as the unique and interesting features associated with electrospun nanofibres, all make these techniques and their resultant structures attractive for various applications such as filtration, drug delivery, sensor devices, tissue engineering scaffolds, would dressing etc.

Nanotechnology for water remediation will play an increasingly crucial role in water security and consequently the food security of the world. Nanoscale filtration techniques, the adsorption of pollutants on nanoparticles and the breakdown of contaminants by nanoparticle catalysts are the major applications of nanotechnology in the clean-up of contaminated water [8-10]. The advantages of electrospun nanofibre membranes are that they can offer both adsorption and filtration characteristics. Therefore, nanofibre membranes offer an attractive solution of heavy metals removal. In this context, green electrospun fibres and membranes are emerging and innovative materials for environmental bioremediation application.

\section{Natural gums for the removal of toxic metal ions}

Heavy metals ( $\mathrm{Pb}, \mathrm{Ni}, \mathrm{Cu}, \mathrm{Zn}, \mathrm{Cr}, \mathrm{As}, \mathrm{Hg}, \mathrm{As}$, and $\mathrm{U}$ ) are a serious biological problem in aquatic systems. Adsorption and filtration are the commonly used methods for removal of these contaminants from the water. In a recent study, gums have been successfully used for the removal of various toxic heavy metals and radioactive and industrial effluents [108-112, 139, 169, 170-175]. The experimental results showed that sorption, ion-exchange, functional group interactions, modified surface properties, and high surface areas were the possible mechanisms for the adsorption of toxic metals onto gum structures [108-112, 139, 169, 170-175].

\section{Electrospinning gum nanofibre for the removal of nanoparticles}

There are potential environmental and health impacts of engineered nanomaterials due to the increased presence of nanomaterials in commercial products. Currently, most sectors of nanotechnology are developing with no guidelines and in an environment ideally suited for entrepreneurship. The lack of disposal of such products will lead to potential contamination of water and ecosystems [176]. Nanomaterials are emerging contaminants in water and show significant toxicity to living systems. Further studies are still in progress on the fate, transport, and transformation of nanoparticles and nanocomposite bioavailability and exposure of humans and other living species [5, 7, 177]. Electrospinning polymers, with various functionalities and combinations of different types of natural and synthetic polymeric materials and their potential applications for the removal of toxic heavy metals from water, have been comprehensively reported [18].

The electropsun membranes of GA, GK, and KG were effectively used for the removal of metal and metal oxide nanoparticles from water [58, 151, 155]. The nanofibres were treated by methane plasma to improve their physicochemical properties and resulted in high adsorption capacities towards nanoparticles $\left(\mathrm{Ag}, \mathrm{Au}, \mathrm{Pt}, \mathrm{CuO}\right.$, and $\left.\mathrm{Fe}_{3} \mathrm{O}_{4}\right)$ in an assessment with untreated membranes [58, 151, 155]. The adsorption capacities of the membrane for the removal of nanoparticles (NPs) from water diverge in the order $\mathrm{Pt}>\mathrm{Au}>\mathrm{Ag}>\mathrm{CuO}>\mathrm{Fe}_{3} \mathrm{O}_{4}[58,151]$. Figures 5 (e and f), 6 (d and e) and 7 (d and e) show the 
nanoparticles ( $\mathrm{Au}, \mathrm{Ag}$, and $\mathrm{Fe}_{3} \mathrm{O}_{4}$ ) adsorbed onto electrospun fibres. Various adsorption mechanisms such as sorption, functional group interactions, complexation reaction between metal/metal oxide nanoparticles with various functional groups present in nanofibre and modified surface properties such as the balance of hydrophilicity/hydrophobicity, surface free energy, and high surface area of the plasma treated membrane are the possible mechanisms of NPs adsorption onto nanofibres [58, 151].

\section{Natural gum functionalized nanoparticles and nanofibres for anti-bacterial applications}

Many antimicrobial agents, such as metallic/metal oxides ( $\mathrm{Ag}, \mathrm{Au}, \mathrm{Cu}$, and $\mathrm{CuO}$ ), organic agents (quaternary ammonium and DDSA) functionalized with natural polymers (chitosan, tree gums (GA, GK, KG, GT, and GG) and cellulose), have been used in textiles and membranes for bio-medical and antibacterial applications [26, 30, 57, 118, 124, $126-130,132,133,135,137,138,146,152,153,172,177]$.

Vinod et al studied the electrospun membranes of $\mathrm{GK}$ and $\mathrm{KG}$ and both of their nanoparticles $(\mathrm{Ag}$ and $\mathrm{CuO})$ and DDSA functionalized membranes were tested for their anti-bacterial efficiencies [26, 128, 152, 177]. The electrospun membrane was cross-linked by heating to $130^{\circ} \mathrm{C}$ and later by methane plasma treatment in order to improve its antibacterial efficiency $[152,128]$. The anti-microbial activities of the fibres and membranes of natural gums were investigated against Gram-negative Escherichia coli and Pseudomonas aeruginosa, and Gram-positive Staphylococcus aureus. It was found that plasma modification enhances the antibacterial properties of the membrane in comparison to unmodified samples [152]. Figure 8 shows the plasma treated fibres of GA, GK, and their antibacterial properties. This study suggests that plasma modified electrospun membranes may be used as antimicrobial membranes in food, water and environmental applications. Furthermore, natural gum functionalized nanoparticles and DDSA derivatives of these gums provide enhanced antibacterial properties and are an attractive approach for the fabrication of such nanomembranes via electrospinning for applications in the food, pharmaceutical and other industrial fields.

\section{Conclusion and prospects}

The development of an ecologically viable electrospinning process using tree based carbohydrate polymers to produce nanofibres in "green" pathways has been explored. The current development in "green" electrospinning technologies provides important clues to the potential roles of these electrospun membranes in water purification and antibacterial applications. The use of tree based polymers in various applications is relatively rare compared to synthetic polymers due to the incompatibility of the choice of the polymer for particular applications and in some cases due to poor chemical and mechanical properties. Nevertheless, further developments are required to find new functionalized hybrid polymer systems based on natural and synthetic polymers, which are suitable for electrospinning with improved functionalities for various applications. Based on the current studies, it is in no doubt that electrospun nanofibres based on natural hydrocolloids are expected to play a significantly vital role in the future in many important applications, such as water purification, renewable energy, scaffolds in tissue engineering, food, biotechnology, and environmental protection. 
a)

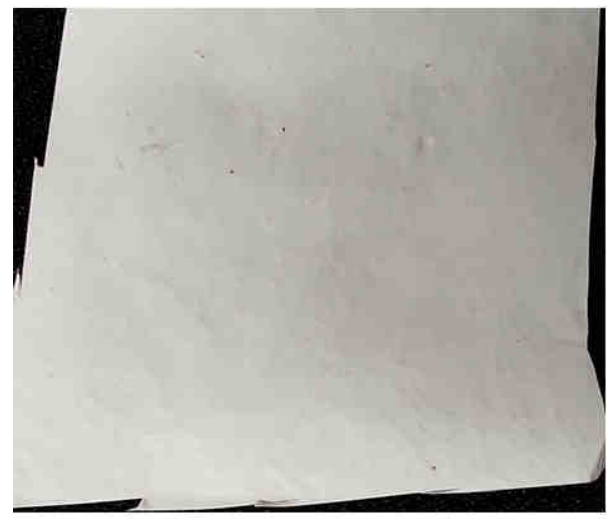

c)

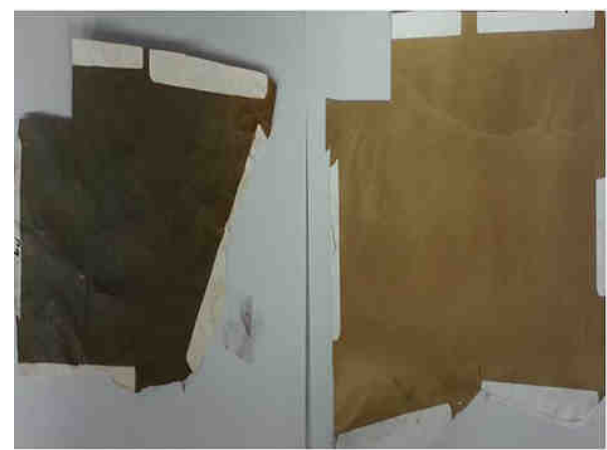

e)

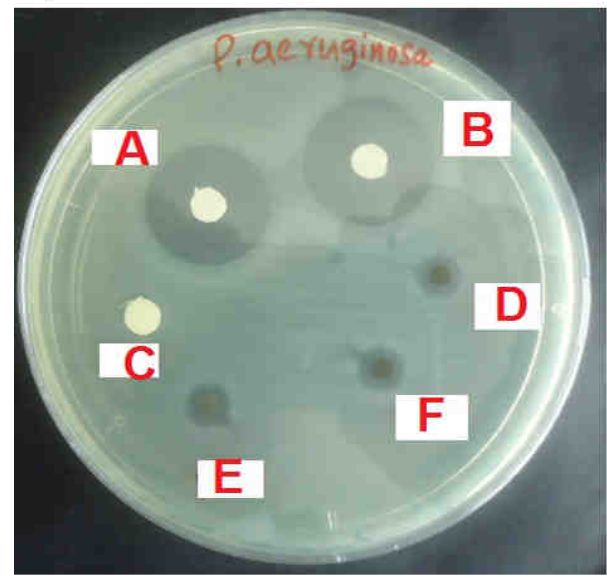

b)

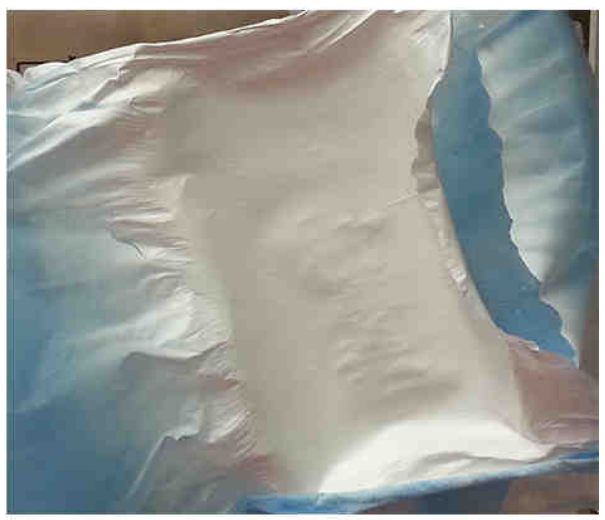

d)

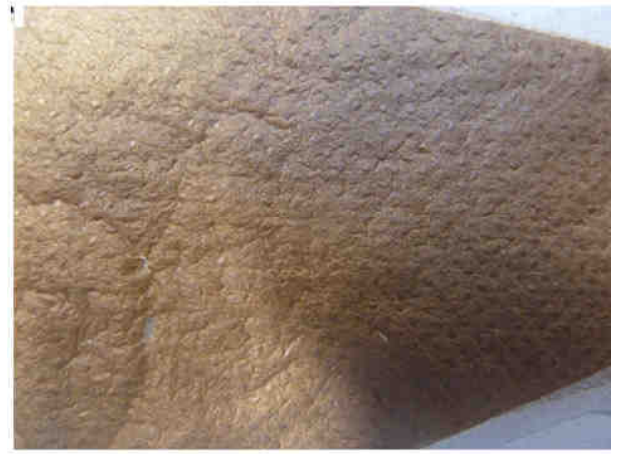

f)

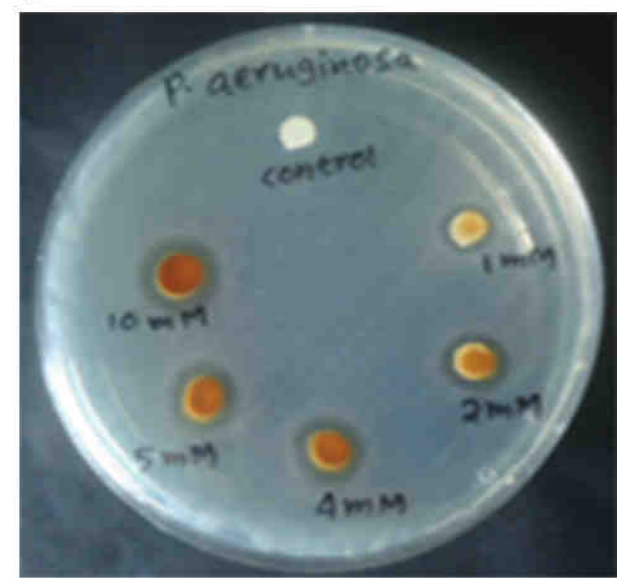

Fig. 8. Electrospun fibres of GA (a, c, and e) and GK (b, d, and f) with their corresponding methane plasma treated membrane showing potential antibacterial efficiencies. A, B (both contain $10 \mathrm{mM}$ of $\mathrm{Ag} / \mathrm{GA}$ ), $\mathrm{C}$ is the control, and $\mathrm{D}, \mathrm{E}$ and $\mathrm{F}$ contain $1 \mathrm{mM}$ of $\mathrm{Ag} / \mathrm{GA}$ fibre; $\mathrm{f}$ ) $\mathrm{Ag} / \mathrm{GK}$ plasma treated membrane containing $\mathrm{Ag}$ from 1 to $10 \mathrm{mM}$ 


\section{Acknowledgements}

The study was supported by the project LO1201, the financial support of the Ministry of Education, Youth and Sports in the framework of the targeted support of the "National Programme for Sustainability I" and the OPR\&DI project "Centre for Nanomaterials, Advanced Technologies and Innovation - CZ.1.05/2.1.00/01.0005". The authors also acknowledge the assistance provided by the Research Infrastructure NanoEnviCz, supported by the Ministry of Education, Youth and Sports of the Czech Republic under Project No. LM2015073.

\section{References}

[1] Fryxell GE, Cao G. Environmental Applications of Nanomaterials: Synthesis, Sorbents and Sensors. London: Imperial College Press; 2007.

[2] Thavasi V, Singh G, Ramakrishna S, D'Amato G, Veleirinho B, Rei MF, et al. Electrospun nanofibers in energy and environmental applications. Energy Environ Sci. 2008;1:205. DOI: 10.1039/b809074m.

[3] Vigneswaran S, Unesco. Water and Wastewater Treatment Technologies; Vol. 1. Oxford: EOLSS Publ; 2009.

[4] Matlack AS. Introduction to green chemistry. New York/London: CRC Press; 2010.

[5] Colvin VL. The potential environmental impact of engineered nanomaterials. Nat Biotechnol. 2003;21:1166-1170. DOI: 10.1038/nbt875.

[6] Dwivedi AD, Dubey SP, Sillanpää M, Kwon Y-N, Lee C, Varma RS. Fate of engineered nanoparticles: Implications in the environment. Coord Chem Rev. 2015;287:64-78. DOI: 10.1016/j.ccr.2014.12.014.

[7] Sharma VK, Filip J, Zboril R, Varma RS, Rizzello L, Pompa PP, et al. Natural inorganic nanoparticles formation, fate, and toxicity in the environment. Chem Soc Rev. 2015;44:8410-23. DOI: 10.1039/C5CS00236B.

[8] Grassian VH. Nanoscience and Nanotechnology: Environmental and Health Impacts. Wiley; 2008. DOI: $10.1002 / 9780470396612$

[9] Varma RS. Greener and sustainable trends in synthesis of organics and nanomaterials. ACS Sustain Chem Eng. 2016;4:5866-5878. DOI: 10.1021/acssuschemeng.6b01623.

[10] Varma RS. Nano-catalysts with magnetic core: sustainable options for greener synthesis. Sustain Chem Process 2014;2:11. DOI: 10.1186/2043-7129-2-11.

[11] Anastas PT, Warner JC. Green Chemistry: Theory and Practice. New York: Oxford University Press; 1998.

[12] Shamim N, Sharma VK, editors. Sustainable Nanotechnology and the Environment: Advances and Achievements; vol. 1124. Washington, DC: American Chemical Society; 2013. DOI: 10.1021/bk-2013-1124.

[13] Luque R, Varma RS, editors. Sustainable Preparation of Metal Nanoparticles. Cambridge: Royal Society of Chemistry; 2012. DOI: 10.1039/9781849735469.

[14] Virkutyte J, Varma RS, Kumar V, Yadav SK, Dahl JA, Maddux BLS, et al. Green synthesis of metal nanoparticles: Biodegradable polymers and enzymes in stabilization and surface functionalization. Chem Sci. 2011;2:837-846. DOI: 10.1039/C0SC00338G.

[15] Iravani S, Klefenz H, Chan WCW, Nie S, Tian Z, Ren B, et al. Green synthesis of metal nanoparticles using plants. Green Chem. 2011;13:2638. DOI: 10.1039/c1gc15386b.

[16] Hebbalalu D, Lalley J, Nadagouda MN, Varma RS. Greener techniques for the synthesis of silver nanoparticles using plant extracts, enzymes, bacteria, biodegradable polymers, and microwaves. ACS Sustain Chem Eng. 2013;1:703-712. DOI: 10.1021/sc4000362.

[17] Raveendran P, Fu J, Wallen SL. Completely "green" synthesis and stabilization of metal nanoparticles. J Am Chem Soc. 2003; 125(46), 13940-13941. DOI: 10.1021/JA029267J.

[18] Pereao OK, Bode-Aluko C, Ndayambaje G, Fatoba O, Petrik LF. Electrospinning: Polymer nanofibre adsorbent applications for metal ion removal. $J$ Polym Environ. 2016:1-15. DOI: 10.1007/s10924-016-0896-y.

[19] Jayaraman K, Kotaki M, Zhang Y, Mo X, Ramakrishna S. Recent advances in polymer nanofibers. J Nanosci Nanotechnol. 2004;4:52-65.

[20] Greiner A, Wendorff JH. Electrospinning: A fascinating method for the preparation of ultrathin fibers. Angew Chemie Int Ed. 2007;46:5670-5703. DOI: 10.1002/anie.200604646.

[21] Nie H, He A, Zheng J, Xu S, Li J, Han CC. effects of chain conformation and entanglement on the electrospinning of pure alginate. Biomacromolecules. 2008;9:1362-1365. DOI: 10.1021/bm701349j. 
[22] Zain NM, Stapley AGF, Shama G. Green synthesis of silver and copper nanoparticles using ascorbic acid and chitosan for antimicrobial applications. Carbohydr Polym. 2014;112:195-202. DOI: 10.1016/j.carbpol.2014.05.081.

[23] Vasileva P, Donkova B, Karadjova I, Dushkin C. Synthesis of starch-stabilized silver nanoparticles and their application as a surface plasmon resonance-based sensor of hydrogen peroxide. Colloids Surfaces A Physicochem Eng Asp. 2011;382:203-10. DOI: 10.1016/j.colsurfa.2010.11.060.

[24] Sarma TK, Chattopadhyay A. Starch-mediated shape-selective synthesis of Au nanoparticles with tunable longitudinal plasmon resonance. Langmuir. 2004;20(9):3520-3524. DOI: 10.1021/LA049970G.

[25] Lokanathan AR, Uddin KMA, Rojas OJ, Laine J. Cellulose nanocrystal-mediated synthesis of silver nanoparticles: role of sulfate groups in nucleation phenomena. Biomacromolecules. 2014;15:373-379. DOI: $10.1021 / \mathrm{bm} 401613 \mathrm{~h}$.

[26] Kora AJ, Sashidhar RB. Antibacterial activity of biogenic silver nanoparticles synthesized with gum ghatti and gum olibanum: a comparative study. J Antibiot. 2015;68:88-97. DOI: 10.1038/ja.2014.114.

[27] Wu C-C, Chen D-H. Facile green synthesis of gold nanoparticles with gum arabic as a stabilizing agent and reducing agent. Gold Bull. 2010;43:234-240. DOI: 10.1007/BF03214993.

[28] Kong H, Yang J, Zhang Y, Fang Y, Nishinari K, Phillips GO. Synthesis and antioxidant properties of gum arabic-stabilized selenium nanoparticles. Int J Biol Macromol. 2014;65:155-162. DOI: 10.1016/j.ijbiomac.2014.01.011.

[29] Vinod VTP, Sashidhar RB, Sukumar AA. Competitive adsorption of toxic heavy metal contaminants by gum kondagogu (Cochlospermum gossypium): A natural hydrocolloid. Colloids Surfaces B Biointerfaces. 2010;75:490-495. DOI: 10.1016/j.colsurfb.2009.09.023.

[30] Peralta-Videa JR, Huang Y, Parsons JG, Zhao L, Lopez-Moreno L, Hernandez-Viezcas JA, et al. Plant-based green synthesis of metallic nanoparticles: scientific curiosity or a realistic alternative to chemical synthesis? Nanotechnol Environ Eng. 2016;1:4. DOI: 10.1007/s41204-016-0004-5.

[31] Shankar SS, Ahmad A, Sastry M. Geranium leaf assisted biosynthesis of silver nanoparticles. Biotechnol Prog. 2003;19:1627-1631. DOI: 10.1021/bp034070w.

[32] Shankar SS, Ahmad A, Pasricha R, Sastry M, Lovley DR, Stolz JF, et al. Bioreduction of chloroaurate ions by geranium leaves and its endophytic fungus yields gold nanoparticles of different shapes. J Mater Chem. 2003;13:1822. DOI: 10.1039/b303808b.

[33] Shankar SS, Rai A, Ahmad A, Sastry M. Rapid synthesis of Au, Ag, and bimetallic Au core-Ag shell nanoparticles using Neem (Azadirachta indica) leaf broth. J Colloid Interface Sci. 2004;275:496-502. DOI: 10.1016/j.jcis.2004.03.003.

[34] Selvakannan P, Sastry M, Mandal S, Roy D, Chaudhari RV, Sastry M, et al. Hollow gold and platinum nanoparticles by a transmetallation reaction in an organic solution. Chem Commun. 2005;16:1684. DOI: $10.1039 / \mathrm{b} 418566 \mathrm{~h}$.

[35] Vilchis-Nestor AR, Sánchez-Mendieta V, Camacho-López MA, Gómez-Espinosa RM, Camacho-López MA, Arenas-Alatorre JA. Solventless synthesis and optical properties of Au and Ag nanoparticles using Camellia sinensis extract. Materials Lett. 2008;62. DOI: 10.1016/j.matlet.2008.01.138.

[36] Lincoln EP, Koopman B, Bagnall LO, Nordstedt RA. Aquatic system for fuel and feed production from livestock wastes. J Agric Eng Res. 1986;33:159-169. DOI: 10.1016/S0021-8634(86)80046-4.

[37] Makarov VV, Love AJ, Sinitsyna OV, Makarova SS, Yaminsky IV, Taliansky ME, et al. Green nanotechnologies: synthesis of metal nanoparticles using plants. Acta Naturae. 2014;6:35-44.

[38] Hutchison JE. Greener nanoscience: A proactive approach to advancing applications and reducing implications of nanotechnology. ACS Nano. 2008;2:395-402. DOI: 10.1021/nn800131j.

[39] Mosaferi M, Nemati S, Khataee A, Nasseri S, Hashemi A, Ravenscroft P, et al. Removal of arsenic (III, V) from aqueous solution by nanoscale zero-valent iron stabilized with starch and carboxymethyl cellulose. J Environ Heal Sci Eng. 2014;12:74. DOI: 10.1186/2052-336X-12-74.

[40] Reicha FM, Sarhan A, Abdel-Hamid MI, El-Sherbiny IM. Preparation of silver nanoparticles in the presence of chitosan by electrochemical method. Carbohydr Polym. 2012;89:236-244. DOI: 10.1016/j.carbpol.2012.03.002.

[41] Long Y, Ran X, Zhang L, Guo Q, Yang T, Gao J, et al. A method for the preparation of silver nanoparticles using commercially available carboxymethyl chitosan and sunlight. Materials Lett. 2013;112:101-104. DOI: 10.1016/j.matlet.2013.09.035.

[42] Vigneshwaran N, Nachane RP, Balasubramanya RH, Varadarajan PV. A novel one-pot "green" synthesis of stable silver nanoparticles using soluble starch. Carbohydr Res. 2006;341:2012-8. DOI: 10.1016/j.carres.2006.04.042.

[43] Yang J, Pan J. Hydrothermal synthesis of silver nanoparticles by sodium alginate and their applications in surface-enhanced Raman scattering and catalysis. Acta Mater. 2012;60:4753-4758. DOI: 10.1016/j.actamat.2012.05.037. 
[44] Zhang R, Edgar KJ. Properties, chemistry, and applications of the bioactive polysaccharide curdlan. Biomacromolecules. 2014;15:1079-1096. DOI: 10.1021/bm500038g.

[45] Zhao X, Xia Y, Li Q, Ma X, Quan F, Geng C, et al. Microwave-assisted synthesis of silver nanoparticles using sodium alginate and their antibacterial activity. Colloids Surfaces A Physicochem Eng Asp. 2014;444:180-188. DOI: 10.1016/j.colsurfa.2013.12.008.

[46] Bankura KP, Maity D, Mollick MMR, Mondal D, Bhowmick B, Bain MK, et al. Synthesis, characterization and antimicrobial activity of dextran stabilized silver nanoparticles in aqueous medium. Carbohydr Polym. 2012;89:1159-1165. DOI: 10.1016/j.carbpol.2012.03.089.

[47] Chen J, Wang J, Zhang X, Jin Y. Microwave-assisted green synthesis of silver nanoparticles by carboxymethyl cellulose sodium and silver nitrate. Mater Chem Phys. 2008;108:421-424. DOI: 10.1016/j.matchemphys.2007.10.019.

[48] El-Rafie MH, El-Naggar ME, Ramadan MA, Fouda MMG, Al-Deyab SS, Hebeish A. Environmental synthesis of silver nanoparticles using hydroxypropyl starch and their characterization. Carbohydr Polym. 2011;86:630-635. DOI: 10.1016/j.carbpol.2011.04.088.

[49] Hebeish A, El-Rafie MH, El-Sheikh MA, El-Naggar ME. Nanostructural features of silver nanoparticles powder synthesized through concurrent formation of the nanosized particles of both starch and silver. J Nanotechnol. 2013:1-10. DOI: 10.1155/2013/201057.

[50] Hebeish A, Farag S, Sharaf S, Shaheen TI. Nanosized carbamoylethylated cellulose as novel precursor for preparation of metal nanoparticles. Fibers Polym. 2015;16:276-284. DOI: 10.1007/s12221-015-0276-6.

[51] Hebeish AA, El-Rafie MH, Abdel-Mohdy FA, Abdel-Halim ES, Emam HE. Carboxymethyl cellulose for green synthesis and stabilization of silver nanoparticles. Carbohydr Polym. 2010;82:933-941. DOI: 10.1016/j.carbpol.2010.06.020.

[52] Kanmani P, Lim ST. Synthesis and characterization of pullulan-mediated silver nanoparticles and its antimicrobial activities. Carbohydr Polym. 2013;97:421-428. DOI: 10.1016/j.carbpol.2013.04.048.

[53] Johnson RL, Nurmi JT, O’Brien Johnson GS, Fan D, O’Brien Johnson RL, Shi Z, et al. Field-scale transport and transformation of carboxymethylcellulose-stabilized nano zero-valent iron. Environ Sci Technol. 2013;47:1573-1580. DOI: 10.1021/es304564q.

[54] El-Naggar ME, Shaheen TI, Fouda MMG, Hebeish AA. Eco-friendly microwave-assisted green and rapid synthesis of well-stabilized gold and core-shell silver-gold nanoparticles. Carbohydr Polym. 2016;136:1128-1136. DOI: 10.1016/j.carbpol.2015.10.003.

[55] Wang B, Chen K, Jiang S, Reincke F, Tong W, Wang D et al. Chitosan-mediated synthesis of gold nanoparticles on patterned poly(dimethylsiloxane) surfaces. Biomacromolecules. 2006;7:1203-1209. DOI: 10.1021/BM060030F.

[56] Wu C-C, Chen D-H. Spontaneous synthesis of gold nanoparticles on gum arabic-modified iron oxide nanoparticles as a magnetically recoverable nanocatalyst. Nanoscale Res Lett. 2012;7:317. DOI: 10.1186/1556-276X-7-317.

[57] Venkatesham M, Ayodhya D, Madhusudhan A, Veerabhadram G. Synthesis of stable silver nanoparticles using gum acacia as reducing and stabilizing agent and study of its microbial properties: A novel green approach. Int J Green Nanotechnol. 2012;4:199-206. DOI: 10.1080/19430892.2012.705999.

[58] Padil VVT, Černík M. Poly (vinyl alcohol)/gum karaya electrospun plasma treated membrane for the removal of nanoparticles ( $\mathrm{Au}, \mathrm{Ag}, \mathrm{Pt}, \mathrm{CuO}$ and $\left.\mathrm{Fe}_{3} \mathrm{O}_{4}\right)$ from aqueous solutions. J Hazard Mater. 2015;287:102-110. DOI: 10.1016/j.jhazmat.2014.12.042.

[59] Nadagouda MN, Polshettiwar V, Varma RS, Sun S, Murray CB, Weller D, et al. Self-assembly of palladium nanoparticles: synthesis of nanobelts, nanoplates and nanotrees using vitamin B1, and their application in carbon-carbon coupling reactions. J Mater Chem. 2009;19:2026. DOI: 10.1039/b817112b.

[60] Nadagouda MN, Varma RS, Zou B, Ceyhan B, Simon U, Niemeyer CM, et al. Green and controlled synthesis of gold and platinum nanomaterials using vitamin B2: density-assisted self-assembly of nanospheres, wires and rods. Green Chem. 2006;8:516. DOI: 10.1039/b601271j.

[61] Nadagouda MN, Varma RS. A greener synthesis of core (Fe, $\mathrm{Cu}$ )-shell ( $\mathrm{Au}, \mathrm{Pt}, \mathrm{Pd}$, and $\mathrm{Ag}$ ) nanocrystals using aqueous vitamin C. Cryst Growth Des. 2007;7:2582-7. DOI: 10.1021/cg070554e.

[62] Nadagouda MN, Varma RS, Wang X, Li Y, Sun Y, Xia Y, et al. Green synthesis of silver and palladium nanoparticles at room temperature using coffee and tea extract. Green Chem. 2008;10:859. DOI: $10.1039 / \mathrm{b} 804703 \mathrm{k}$.

[63] Kou J, Varma RS. Beet juice - induced green fabrication of plasmonic $\mathrm{AgCl} / \mathrm{Ag}$ nanoparticles. Chem Sus Chem. 2012;5:2435-2441. DOI: 10.1002/cssc.201200477.

[64] Kou J, Varma RS, Guo S, Wang E, Sau TK, Rogach AL, et al. Beet juice utilization: Expeditious green synthesis of noble metal nanoparticles (Ag, Au, Pt, and Pd) using microwaves. RSC Adv. 2012;2:10283. DOI: $10.1039 / \mathrm{c} 2 \mathrm{ra} 21908 \mathrm{e}$. 
[65] Baruwati B, Varma RS. High value products from waste: grape pomace extract - a three-in-one package for the synthesis of metal nanoparticles. Chem Sus Chem. 2009;2:1041-1044.

[66] Anderson DM, Wang WP. Composition of the gum from Combretum paniculatum and four other gums which are not permitted food additives. Phytochemistry. 1990;29:1193-1195.

[67] Anderson DMW, Weiping W. Gum arabic (Acacia Senegal) from Uganda: Characteristic N.M.R. Spectra, amino acid compositions, and gum/soil cationic relationships. Int Tree Crop J. 1992;7:167-179. DOI: 10.1080/01435698.1992.9752915.

[68] Anderson DMW, Mcnab CGA, Anderson CG, Brown PM, Pringuer MA. Studies of uronic acid materials, Part 58: Gum exudates from the Genus Sterculia (Gum Karaya). Int Tree Crop J. 1983;2:147-154. DOI: $10.1080 / 01435698.1983 .9752749$.

[69] Anderson DMW, Bridgeman MME. The composition of the proteinaceous polysaccharides exuded by astragalus microcephalus, A. Gummifer and A. Kurdicus - The sources of Turkish gum tragacanth. Phytochemistry. 1985;24:2301-2304. DOI: 10.1016/S0031-9422(00)83031-9.

[70] Anderson DMW, Howlett JF, McNab CGA. The amino acid composition of the proteinaceous component of gum arabic (Acacia Senegal (L.) Willd.). Food Addit Contam. 1985;2:159-164. DOI: 10.1080/02652038509373539.

[71] Anderson DMW, Howlett JF, McNab CGA. The amino acid composition of the proteinaceous component of gum karaya (Sterculia spp.). Food Addit Contam. 1985;2:153-157. DOI: 10.1080/02652038509373538.

[72] Anderson DMW, Yin XS. The amino acid composition and quantitative sugar-amino acid relationships in sequential Smith-degradation products from gum talha (Acacia seyal Del.). Food Addit Contam. 1988;5:1-8. DOI: $10.1080 / 02652038809373656$.

[73] Hall SR. Biotemplating. Imperial College Press; 2009. DOI: 10.1142/p646.

[74] Phillips GO, Williams PA. Tree exudates gums: natural and versatile food additives and ingredients. Food Ingred Anal Internat. 2001;23:26-28.

[75] Phillips GO, Williams PA. Handbook of Hydrocolloids. Cambridge: Woodhead Pub; 2009; 155-168.

[76] Kennedy JF, Phillips GO, Williams PA, editors. Gum Arabic. Cambridge: Royal Society of Chemistry; 2011. DOI: $10.1039 / 9781849733106$.

[77] Williams PA, Phillips GO. Gum Arabic. Cambridge: Woodhead Publishers LTD Press; 2009; 252-273.

[78] Verbeken D, Dierckx S, Dewettinck K. Exudate gums: occurrence, production, and applications. Appl Microbiol Biotechnol. 2003;63:10-21. DOI: 10.1007/s00253-003-1354-z.

[79] Vinod VTP, Sashidhar RB, Suresh KI, Rama Rao B, Vijaya Saradhi UVR, Prabhakar Rao T. Morphological, physico-chemical and structural characterization of gum kondagogu (Cochlospermum gossypium): A tree gum from India. Food Hydrocoll. 2008;22:899-915. DOI: 10.1016/j.foodhyd.2007.05.006.

[80] Vinod VTP, Sashidhar RB, Sarma VUM, Vijaya Saradhi UVR. Compositional analysis and rheological properties of gum kondagogu (Cochlospermum gossypium): A tree gum from India. J Agric Food Chem. 2008;56:2199-207. DOI: 10.1021/jf072766p.

[81] Anderson DMW, Dea ICM. Studies on uronic acid materials: Part XXX. Examination of three fractions obtained from acacia drepanolobium gum. Carbohydr Res. 1968;8:440-447. DOI: 10.1016/S0008-6215(00)81528-1.

[82] Fauconnier ML, Blecker C, Groyne J, Razafindralambo H, Vanzeveren E, Marlier M, et al. Characterization of two Acacia gums and their fractions using a langmuir film balance. J Agric Food Chem. 2000;48:2709-2712.

[83] Osman ME, Menzies AR, Williams PA, Phillips GO, Baldwin TC. The molecular characterisation of the polysaccharide gum from Acacia senegal. Carbohydr Res. 1993;246:303-318. DOI: 10.1016/0008-6215(93)84042-5.

[84] Osman ME, Williams PA, Menzies AR, Phillips GO. Characterization of commercial samples of gum arabic. J Agric Food Chem. 1993;41:71-77. DOI: 10.1021/jf00025a016.

[85] Osman ME, Menzies AR, Martin BA, Williams PA, Phillips GO, Baldwin TC. Characterization of gum arabic fractions obtained by anion-exchange chromatography. Phytochemistry. 1995;38:409-417. DOI: 10.1016/0031-9422(94)00645-A.

[86] Randall RC, Phillips GO, Williams PA. Fractionation and characterization of gum from Acacia senegal. Food Hydrocoll. 1989;3:65-75. DOI: 10.1016/S0268-005X(89)80034-7.

[87] Mahendran T, Williams PA, Phillips GO, Al-Assaf S, Baldwin TC. New insights into the structural characteristics of the arabinogalactan-protein (AGP) fraction of gum arabic. J Agric Food Chem. 2008;56:9269-9276. DOI: 10.1021/jf800849a.

[88] Phillips GO, Williams PA. Handbook of Hydrocolloids. Woodhead Pub; 2009.

[89] Padala SR, Williams PA, Phillips GO. Adsorption of gum arabic, egg white protein, and their mixtures at the oil-water interface in limonene oil-in-water emulsions. J Agric Food Chem. 2009;57:4964-4973. DOI: $10.1021 /$ jf803794n. 
[90] Randall RC, Phillips GO, Williams PA. The role of the proteinaceous component on the emulsifying properties of gum arabic. Food Hydrocoll. 1988;2:131-140. DOI: 10.1016/S0268-005X(88)80011-0.

[91] Anderson DMW, Grant DAD. The chemical characterization of some Astragalus gum exudates. Food Hydrocoll. 1988;2:417-423. DOI: 10.1016/S0268-005X(88)80006-7.

[92] Phillips GO, Williams PA. Handbook of Hydrocolloids. CRC Press; 2000.

[93] Verotta L, El-Sebakhy NA. Cycloartane and oleanane saponins from Astragalus sp. Stud Nat Prod Chem. 2001;25:179-234. DOI: 10.1016/S1572-5995(01)80008-9.

[94] Singh B, Sharma V. Influence of polymer network parameters of tragacanth gum-based $\mathrm{pH}$ responsive hydrogels on drug delivery. Carbohydr Polym. 2014;101:928-940. DOI: 10.1016/j.carbpol.2013.10.022.

[95] Stephen AM, Phillips GO, Williams PA, editors. Food Polysaccharides and their Applications. Boca Raton, London, New York: CRC Press. Taylor \& Francis; 2006. https://tngmai.files.wordpress.com/2012/10/foodpolysaccharidestheirapplications.pdf

[96] Anderson DMW, McNab CGA, Anderson CG, Brown PM, Pringuer MA. Studies of uronic acid materials. 58. Gum exudates from the genus Sterculia (gum karaya). Int Tree Crop J. 1983. DOI: $10.1080 / 01435698.1983 .9752749$

[97] Le Cerf D, Irinei F, Muller G. Solution properties of gum exudates from Sterculia urens (Karaya gum). Carbohydr Polym. 1990;13:375-386. DOI: 10.1016/0144-8617(90)90037-S.

[98] Brito ACF, Silva DA, de Paula RCM, Feitosa JPA. Sterculia striata exudate polysaccharide: characterisation, rheological properties and comparison with Sterculia urens (karaya) polysaccharide. Polym Inter. 2004;53:1025-1032. DOI: 10.1002/pi.1468

[99] de Brito ACF, Sierakowski MR, Reicher F, Feitosa JPA, de Paula RCM. Dynamic rheological study of Sterculia striata and karaya polysaccharides in aqueous solution. Food Hydrocoll. 2005;19:861-867. DOI: 10.1016/j.foodhyd.2004.10.035.

[100] Whistler RL, BeMiller JN. Industrial Gums: Polysaccharides and their Derivatives. Third Ed. San Diego: Academic Press; 1993.

[101] Janaki B, Sashidhar R. Physico-chemical analysis of gum kondagogu (Cochlospermum gossypium): a potential food additive. Food Chem. 1998;61:231-236. DOI: 10.1016/S0308-8146(97)00089-7.

[102] Idu M, Uzoekwe S, Onyibe HI. Nutritional evaluation of Sterculia setigera seeds and pod. Pakistan J Biol Sci. PJBS 2008;11:139-141.

[103] Janaki B, Sashidhar RB. Subchronic (90-day) toxicity study in rats fed gum kondagogu (Cochlospermumgossypium). Food Chem Toxicol. 2000;38:523-534.

[104] Vegi GMN, Sistla R, Srinivasan P, Beedu SR, Khar RK, Diwan P V. Emulsifying properties of gum kondagogu ( Cochlospermum gossypium ), a natural biopolymer. J Sci Food Agric. 2009;89:1271-1276. DOI: $10.1002 /$ jsfa.3568.

[105] Naidu VGM, Madhusudhana K, Sashidhar RB, Ramakrishna S, Khar RK, Ahmed FJ, et al. Polyelectrolyte complexes of gum kondagogu and chitosan, as diclofenac carriers. Carbohydr Polym. 2009;76:464-471. DOI: 10.1016/j.carbpol.2008.11.010.

[106] Vinod VTP, Sashidhar RB. Solution and conformational properties of gum kondagogu (Cochlospermum gossypium) - A natural product with immense potential as a food additive. Food Chem. 2009;116:686-692. DOI: 10.1016/j.foodchem.2009.03.009.

[107] Vinod VTP, Sashidhar RB, Sarma VUM, Raju SS. Comparative amino acid and fatty acid compositions of edible gums kondagogu (Cochlospermum gossypium) and karaya (Sterculia urens). Food Chem. 2010;123:57-62. DOI: 10.1016/j.foodchem.2010.03.127.

[108] Vinod VTP, Sashidhar RB, Sreedhar B. Biosorption of nickel and total chromium from aqueous solution by gum kondagogu (Cochlospermum gossypium): A carbohydrate biopolymer. J Hazard Mater. 2010;178:851-860. DOI: 10.1016/j.jhazmat.2010.02.016.

[109] Vinod VTP, Sashidhar RB, Sreedhar B, Rama Rao B, Nageswara Rao T, Abraham JT. Interaction of Pb2+ and $\mathrm{Cd} 2+$ with gum kondagogu (Cochlospermum gossypium): A natural carbohydrate polymer with biosorbent properties. Carbohydr Polym. 2009;78:894-901. DOI: 10.1016/j.carbpol.2009.07.025.

[110] Vinod V, Sashidhar R, Černík M. Morphology and metal binding characteristics of a natural polymer kondagogu (Cochlospermum gossypium) gum. Molecules. 2013;18:8264-8274. DOI: 10.3390/molecules18078264.

[111] Saravanan P, Vinod VTP, Sreedhar B, Sashidhar RB. Gum kondagogu modified magnetic nano-adsorbent: An efficient protocol for removal of various toxic metal ions. Mater Sci Eng C. 2012;32:581-586. DOI: 10.1016/j.msec.2011.12.015.

[112] Vinod VTP, Sashidhar RB, Sukumar AA. Competitive adsorption of toxic heavy metal contaminants by gum kondagogu (Cochlospermum gossypium): A natural hydrocolloid. Colloids Surfaces B Biointerfaces. 2010;75:490-495. DOI: 10.1016/j.colsurfb.2009.09.023. 
[113] Davidson RL, editor. Handbook of Water-Soluble Gums and Resins. New York: McGraw-Hill; 1980. http://trove.nla.gov.au/version/10638860.

[114] Panda H. The Complete Technology Book on Natural Products (Forest Based). Asia Pacific Business Press; 2002.

[115] Kang J, Cui SW, Chen J, Phillips GO, Wu Y, Wang Q. New studies on gum ghatti (Anogeissus latifolia) part I. Fractionation, chemical and physical characterization of the gum. Food Hydrocoll. 2011;25:1984-1990. DOI: 10.1016/j.foodhyd.2010.12.011.

[116] Kang J, Cui SW, Phillips GO, Chen J, Guo Q, Wang Q. New studies on gum ghatti (Anogeissus latifolia) Part III: Structure characterization of a globular polysaccharide fraction by 1D, 2D NMR spectroscopy and methylation analysis. Food Hydrocoll. 2011;25:1999-2007. DOI: 10.1016/j.foodhyd.2010.11.020.

[117] Castellani O, Al-Assaf S, Axelos M, Phillips GO, Anton M. Hydrocolloids with emulsifying capacity. Part 2 - Adsorption properties at the n-hexadecane-water interface. Food Hydrocoll. 2010;24:121-130. DOI: 10.1016/j.foodhyd.2009.07.006.

[118] Deshmukh AS, Setty CM, Badiger AM, Muralikrishna KS. Gum ghatti: A promising polysaccharide for pharmaceutical applications. Carbohydr Polym. 2012;87:980-986. DOI: 10.1016/j.carbpol.2011.08.099.

[119] Mohan YM, Raju KM, Sambasivudu K, Singh S, Sreedhar B. Preparation of acacia-stabilized silver nanoparticles: A green approach. J Appl Polym Sci. 2007;106:3375-3381. DOI: 10.1002/app.26979.

[120] Akele ML, Assefa AG, Alle M. Microwave-assisted green synthesis of silver nanoparticles by using gum acacia: Synthesis, characterization and catalytic activity studies. Int $\mathrm{J}$ Green Chem Bioprocess. 2015;5:21-27.

[121] Dong C, Zhang X, Cai H, Cao C. Facile and one-step synthesis of monodisperse silver nanoparticles using gum acacia in aqueous solution. J Mol Liq. 2014;196:135-141. DOI: 10.1016/j.molliq.2014.03.009.

[122] Djajadisastra JS, Purnamasari P, Pujiyanto A. Antioxidant activity of gold nanoparticles using gum arabic as a stabilizing agent. Int J Pharm Pharm Sci. 2014;6:462-465.

[123] Thanaa I. Shalaby, Rasha S. Shams El-Dine SAAE-G. Green synthesis of gold nanoparticles using cumin seeds and gum arabic: Studying their photothermal efficiency. Nanosci Nanotechnol. 2015;5:89-96. DOI: 10.5923/j.nn.20150504.03.

[124] Kattumuri V, Katti K, Bhaskaran S, Boote EJ, Casteel SW, Fent GM, et al. Gum arabic as a phytochemical construct for the stabilization of gold nanoparticles: In vivo pharmacokinetics and X-ray-contrast-imaging studies. Small. 2007;3:333-341. DOI: 10.1002/smll.200600427.

[125] Dong C, Cai H, Zhang X, Cao C. Synthesis and characterization of monodisperse copper nanoparticles using gum acacia. Phys E Low-Dimensional Syst Nanostruct. 2014;57:12-20. DOI: 10.1016/j.physe.2013.10.025.

[126] Chockalingam A, Babu $\mathrm{H}$, Chittor R, Tiwari J, Che Y, Li Y, et al. Gum arabic modified $\mathrm{Fe}_{3} \mathrm{O}_{4}$ nanoparticles cross linked with collagen for isolation of bacteria. J Nanobiotechnol. 2010;8:30. DOI: 10.1186/1477-3155-8-30.

[127] Venkatesham M, Ayodhya D, Madhusudhan A, Santoshi Kumari A, Veerabhadram G, Girija Mangatayaru K. A novel green synthesis of silver nanoparticles using gum karaya: Characterization, antimicrobial and catalytic activity studies. J Clust Sci. 2014;25:409-422. DOI: 10.1007/s10876-013-0620-1.

[128] Vinod VTP, Nguyen NHA, Sevcu A, Černík M. Fabrication, characterization, and antibacterial properties of electrospun membrane composed of gum karaya, polyvinyl alcohol, and silver nanoparticles. J Nanomater. 2015. Article ID 750726. DOI: Org/10.1155/2015/750726.

[129] Pooja D, Panyaram S, Kulhari H, Reddy B, Rachamalla SS, Sistla R. Natural polysaccharide functionalized gold nanoparticles as biocompatible drug delivery carrier. Int J Biol Macromol. 2015;80:48-56. DOI: 10.1016/j.ijbiomac.2015.06.022.

[130] Thekkae Padil VV, Černík M. Green synthesis of copper oxide nanoparticles using gum karaya as a biotemplate and their antibacterial application. Int $\mathbf{J}$ Nanomed. 2013;8:889-898. DOI: 10.2147/IJN.S40599.

[131] Vinod VTP, Saravanan P, Sreedhar B, Devi DK, Sashidhar RB. A facile synthesis and characterization of $\mathrm{Ag}$, Au and Pt nanoparticles using a natural hydrocolloid gum kondagogu (Cochlospermum gossypium). Colloids Surfaces B Biointerfaces. 2011;83:291-298. DOI: 10.1016/j.colsurfb.2010.11.035.

[132] Kora AJ, Sashidhar RB, Arunachalam J. Gum kondagogu (Cochlospermum gossypium): A template for the green synthesis and stabilization of silver nanoparticles with antibacterial application. Carbohydr Polym. 2010;82:670-679. DOI: 10.1016/j.carbpol.2010.05.034.

[133] Reddy GB, Madhusudhan A, Ramakrishna D, Ayodhya D, Venkatesham M, Veerabhadram G. Green chemistry approach for the synthesis of gold nanoparticles with gum kondagogu: characterization, catalytic and antibacterial activity. J Nanostructure Chem. 2015;5:185-193. DOI: 10.1007/s40097-015-0149-y. 
[134] Saravanan P, Vinod VTP, Sreedhar B, Sashidhar RB. Gum kondagogu modified magnetic nano-adsorbent: An efficient protocol for removal of various toxic metal ions. Mater Sci Eng C. 2012;32:581-586. DOI: 10.1016/j.msec.2011.12.015.

[135] Kora AJ, Arunachalam J. Green fabrication of silver nanoparticles by gum tragacanth (Astragalus gummifer): A dual functional reductant and stabilizer. $J$ Nanomater. 2012;2012:1-8. DOI: $10.1155 / 2012 / 869765$.

[136] Ghayempour S, Montazer M, Mahmoudi Rad M. Tragacanth gum biopolymer as reducing and stabilizing agent in biosonosynthesis of urchin-like $\mathrm{ZnO}$ nanorod arrays: A low cytotoxic photocatalyst with antibacterial and antifungal properties. Carbohydr Polym. 2016;136:232-421. DOI: 10.1016/j.carbpol.2015.09.001.

[137] Kora A, Beedu S, Jayaraman A. Size-controlled green synthesis of silver nanoparticles mediated by gum ghatti (Anogeissus latifolia) and its biological activity. Org Med Chem Let. 2012;2:17. DOI: 10.1186/2191-2858-2-17.

[138] Kora AJ, Rastogi L. Green synthesis of palladium nanoparticles using gum ghatti (Anogeissus latifolia) and its application as an antioxidant and catalyst. Arab J Chem. 2015. DOI: 10.1016/j.arabjc.2015.06.024.

[139] Mittal H, Mishra SB. Gum ghatti and $\mathrm{Fe}_{3} \mathrm{O}_{4}$ magnetic nanoparticles based nanocomposites for the effective adsorption of rhodamine B. Carbohydr Polym. 2014;101:1255-1264. DOI: 10.1016/j.carbpol.2013.09.045.

[140] Lee KY, Jeong L, Kang YO, Lee SJ, Park WH. Electrospinning of polysaccharides for regenerative medicine. Adv Drug Deliv Rev. 2009;61:1020-1032. DOI: 10.1016/j.addr.2009.07.006.

[141] Matsumoto H, Tanioka A. functionality in electrospun nanofibrous membranes based on fiber's size, surface area, and molecular orientation. Membranes (Basel). 2011;1:249-264. DOI: 10.3390/membranes1030249.

[142] Ramakrishna S, Fujihara K, Teo W-E, Lim T-C, Ma Z. An Introduction to Electrospinning and Nanofibers. World Scientific; 2005. DOI: 10.1142/5894.

[143] Coluzza I, Pisignano D, Gentili D, Pontrelli G, Succi S. Ultrathin fibers from electrospinning experiments under driven fast-oscillating perturbations. Phys Rev Appl. 2014;2:54011. DOI: 10.1103/PhysRevApplied.2.054011.

[144] Yoon K, Hsiao BS, Chu B, Samet JM, Dominici F, Curriero FC, et al. Functional nanofibers for environmental applications. J Mater Chem. 2008;18:5326. DOI: 10.1039/b804128h.

[145] Toskas G, Hund R-D, Laourine E, Cherif C, Smyrniotopoulos V, Roussis V. Nanofibers based on polysaccharides from the green seaweed Ulva Rigida. Carbohydr Polym. 2011;84:1093-1102. DOI: 10.1016/j.carbpol.2010.12.075.

[146] Ranjbar-Mohammadi M, Bahrami SH, Joghataei MT. Fabrication of novel nanofiber scaffolds from gum tragacanth/poly(vinyl alcohol) for wound dressing application: In vitro evaluation and antibacterial properties. Mater Sci Eng C. 2013;33:4935-4943. DOI: 10.1016/j.msec.2013.08.016.

[147] Lubambo AF, de Freitas RA, Sierakowski M-R, Lucyszyn N, Sassaki GL, Serafim BM, et al. Electrospinning of commercial guar-gum: Effects of purification and filtration. Carbohydr Polym. 2013;93:484-491. DOI: 10.1016/j.carbpol.2013.01.031.

[148] Elsabee MZ, Naguib HF, Morsi RE. Chitosan based nanofibers, review. Mater Sci Eng C. 2012;32:1711-1726. DOI: 10.1016/j.msec.2012.05.009.

[149] Homayoni H, Ravandi SAH, Valizadeh M. Electrospinning of chitosan nanofibers: Processing optimization. Carbohydr Polym. 2009;77:656-661. DOI: 10.1016/j.carbpol.2009.02.008.

[150] Vashisth P, Pruthi PA, Singh RP, Pruthi V. Process optimization for fabrication of gellan based electrospun nanofibers. Carbohydr Polym. 2014;109:16-21. DOI: 10.1016/j.carbpol.2014.03.003.

[151] Padil VVT, Stuchlík M, Cerník M. Plasma modified nanofibres based on gum kondagogu and their use for collection of nanoparticulate silver, gold and platinum. Carbohydr Polym. 2015;121:468-476. DOI: 10.1016/j.carbpol.2014.11.074.

[152] Padil VVT, Nguyen NHA, Rożek Z, Ševců A, Černík M. Synthesis, fabrication and antibacterial properties of a plasma modified electrospun membrane consisting of gum kondagogu, dodecenyl succinic anhydride and poly (vinyl alcohol). Surf Coatings Technol. 2015;271:32-38. DOI: 10.1016/j.surfcoat.2015.01.035.

[153] Radhi Addai Z, Abdullah A, Abd Mutalib S, Hamid Musa K. Effect of gum arabic on quality and antioxidant properties of papaya fruit during cold storage. Int J Chem Tech Res. 2013;5:974-4290.

[154] Padil VVT, Senan C, Wacławek S, Černík M. Electrospun fibers based on arabic, karaya and kondagogu gums. Int J Biol Macromol. 2016;91:299-309. DOI: 10.1016/j.ijbiomac.2016.05.064.

[155] Padil VVT, Černík M. Tree gum based electrospun nanofibre membranes: process optimization, characterization and environmental application. Nanocon 2014 Proceedings. http://nanocon2014.tanger.cz/files/proceedings/20/reports/3178.pdf.

[156] Chu P, Chen J, Wang L, Huang N. Plasma-surface modification of biomaterials. Mater Sci Eng R Reports. 2002;36:143-206. DOI: 10.1016/S0927-796X(02)00004-9. 
[157] Guo M, Ding B, Li X, Wang X, Yu J, Wang M. Amphiphobic nanofibrous silica mats with flexible and high-heat-resistant properties. J Phys Chem C. 2010;114:916-921. DOI: 10.1021/jp909672r.

[158] Daw R, Candan S, Beck AJ, Devlin AJ, Brook IM, MacNeil S, et al. Plasma copolymer surfaces of acrylic acid/1,7 octadiene: surface characterisation and the attachment of ROS 17/2.8 osteoblast-like cells. Biomaterials. 1998;19:1717-1725.

[159] Svirachev DM, Tabaliov NA. Plasma Treatment of Polymer Surfaces in Different Gases. Adv. Technol. Based Wave Beam Gener. Plasmas. Dordrecht: Springer Netherlands; 1999; 475-476. DOI: 10.1007/978-94-017-0633-9_23.

[160] Webb K, Hlady V, Tresco PA. Relative importance of surface wettability and charged functional groups on NIH 3T3 fibroblast attachment, spreading, and cytoskeletal organization. J Biomed Mater Res. 1998;41:422-430.

[161] Tan SH, Nguyen N-T, Chua YC, Kang TG. Oxygen plasma treatment for reducing hydrophobicity of a sealed polydimethylsiloxane microchannel. Biomicrofluidics. 2010;4:32204. DOI: 10.1063/1.3466882.

[162] Junkar I, Vesel A, Cvelbar U, Mozetič M, Strnad S. Influence of oxygen and nitrogen plasma treatment on polyethylene terephthalate (PET) polymers. Vacuum. 2009;84:83-85. DOI: 10.1016/j.vacuum.2009.04.011.

[163] Krupa A, Sobczyk AT, Jaworek A. Surface properties of plasma-modified poly(vinylidene fluoride) and poly(vinyl chloride) nanofibres. Fibres Text East Eur. 2014;2(104).

[164] Hilal N, Khayet M, Wright CJ. Membrane Modification: Technology and Applications. Taylor \& Francis; 2012.

[165] Rangel EC, Bento WCA, Kayama ME, Schreiner WH, Cruz NC. Enhancement of polymer hydrophobicity by SF6 plasma treatment and argon plasma immersion ion implantation. Surf Interface Anal. 2003;35:179-183. DOI: 10.1002/sia.1518.

[166] Jeong L, Yeo I-S, Kim HN, Yoon Y Il, Jang DH, Jung SY, et al. Plasma-treated silk fibroin nanofibers for skin regeneration. Int J Biol Macromol. 2009;44:222-228. DOI: 10.1016/j.ijbiomac.2008.12.008.

[167] Nisoa M, Wanichapichart P. Surface hydrophobic modification of cellulose membranes by plasma-assisted deposition of hydrocarbon films. Songklanakarin J Sci Technol. 2010;32:97-101.

[168] Thongphud A, Paosawatyanyong B, Visal-athaphand P, Supaphol P. Improvement of hydrophobic properties of the electrospun PVA fabrics by $\mathrm{SF}_{6}$ plasma treatment. Adv Mater Res. 2008;55-57:625-8. DOI: 10.4028/www.scientific.net/AMR.55-57.625.

[169] Vinod VTP, Sashidhar RB, Sivaprasad N, Sarma VUM, Satyanarayana N, Kumaresan R, et al. Bioremediation of mercury (II) from aqueous solution by gum karaya (Sterculia urens): A natural hydrocolloid. Desalination. 2011;272:270-277. DOI: 10.1016/j.desal.2011.01.027.

[170] Vinod VTP, Sashidhar RB. Bioremediation of industrial toxic metals with gum kondagogu (Cochlospermum gossypium): A natural carbohydrate biopolymer. Indian J Biotech. 2011;10:113-120. http://nopr.niscair.res.in/bitstream/123456789/10959/1/IJBT\%2010(1)\%20113-120.pdf.

[171] Masoumi A, Ghaemy M. Removal of metal ions from water using nanohydrogel tragacanth gum-g-polyamidoxime: Isotherm and kinetic study. Carbohydr Polym. 2014;108:206-215. DOI: 10.1016/j.carbpol.2014.02.083.

[172] Sahraei R, Ghaemy M. Synthesis of modified gum tragacanth/graphene oxide composite hydrogel for heavy metal ions removal and preparation of silver nanocomposite for antibacterial activity. Carbohydr Polym. 2017;157:823-833. DOI: 10.1016/j.carbpol.2016.10.059.

[173] Fosso-Kankeu E, Mittal H, Waanders F, Ntwampe IO, Ray SS. Preparation and characterization of gum karaya hydrogel nanocomposite flocculant for metal ions removal from mine effluents. Int J Environ Sci Technol. 2016;13:711-724. DOI: 10.1007/s13762-015-0915-x.

[174] Banerjee SS, Chen D-H. Fast removal of copper ions by gum arabic modified magnetic nano-adsorbent. J Hazard Mater. 2007;147:792-799. DOI: 10.1016/j.jhazmat.2007.01.079.

[175] Sashidhar RB, Selvi SK, Vinod VTP, Kosuri T, Raju D, Karuna R. Bioprospecting of gum kondagogu (Cochlospermum gossypium) for bioremediation of uranium(VI) from aqueous solution and synthetic nuclear power reactor effluents. J Environ Radioact. 2015;148:33-41. DOI: 10.1016/j.jenvrad.2015.05.016.

[176] Donaldson K, Stone V, Tran CL, Kreyling W, Borm PJA. Nanotoxicology. Occup Environ Med. 2004;61:727-728. DOI: 10.1136/oem.2004.013243.

[177] Padil VVT, Senan C, Černík M. Dodecenylsuccinic anhydride derivatives of gum karaya (Sterculia urens): Preparation, characterization, and their antibacterial properties. J Agric Food Chem. 2015;63:3757-3765. DOI: 10.1021/jf505783e. 